\title{
Taxonomic status of Macaronesian Eucyclops agiloides azorensis (Arthropoda: Crustacea: Copepoda) revisited - morphology suggests a Palearctic origin
}

\author{
Maria HOŁYŃSKA ${ }^{\oplus 1, *}$, Łukasz SŁUGOCKI ${ }^{\circledR 2}$, \\ Souad GHAOUACI ${ }^{\circledR 3}$ \& Mounia AMAROUAYACHE ${ }^{\circledR 4}$ \\ ${ }^{1}$ Museum and Institute of Zoology, Polish Academy of Sciences, \\ Wilcza 64, 00-679 Warszawa, Poland. \\ ${ }^{2}$ University of Szczecin, Institute of Biology, Department of Hydrobiology, \\ Wąska 13, 71-415 Szczecin, Poland. \\ ${ }^{3,4}$ Marine Bioresources Laboratory, Annaba University Badji Mokhtar, \\ BP12 El-Hadjar, Annaba 23002, Algeria. \\ ${ }^{*}$ Corresponding author: mariahol@miiz.waw.pl \\ 2Email: lukasz.slugocki@usz.edu.pl \\ ${ }^{3}$ Email: souad_ghaouaci@yahoo.com \\ [4Email: m.derbal@yahoo.fr

\footnotetext{
${ }^{1}$ urn:lsid:zoobank.org:author:DEFCAC09-2B6A-4030-87D9-A317F189763C

${ }^{2}$ urn:1sid:zoobank.org:author:AE13D1DC-88C7-4A87-A2CD-04EF6CE4062C

${ }^{3}$ urn:Isid:zoobank.org:author:52D5FFB6-48F7-4328-8139-4C3E504A0D3D

${ }^{4}$ urn:lsid:zoobank.org:author:05752CDB-E632-4DE7-994E-FF0001CC910D
}

\begin{abstract}
Macaronesia, with the exception of the Azores, is one of the few Palearctic provinces where basic taxonomic information on the freshwater copepods is still lacking. We redescribed Eucyclops azorensis, a cyclopid crustacean so far known only in the Azores, and report the occurrence of this species in Algeria and Madeira Island. Eucyclops azorensis was formerly considered to be a subspecies of E. agiloides (East Africa); therefore, the latter species is redescribed here as well based on type and nontype material. Morphological comparisons between E. azorensis, E. agiloides and other taxa (E. serrulatus and $E$. roseus), assumed to be closely related to our target species, support a closer relationship between E. azorensis and E. serrulatus (Palearctic) than between E. azorensis and E. agiloides (Afrotropical). The slight differences between E. azorensis and E. serrulatus in the surface ornamentation of the antennal coxobasis and intercoxal sclerites of legs 1 and 4 suggest a relatively young separation of these lineages. Eucyclops agiloides is morphologically close to E. roseus (temperate and subtropical Asia, southeastern Europe, East Africa). The numerous and clear-cut differences indicate a species rather than subspecieslevel differentiation between E. agiloides and E. roseus, unlike what was formerly proposed in the taxonomic literature.
\end{abstract}

Keywords. Cyclopidae, Algeria, Madeira, freshwater, distribution. 
Hołyńska M., Sługocki Ł., Ghaouaci S. \& Amarouayache M. 2021. Taxonomic status of Macaronesian Eucyclops agiloides azorensis (Arthropoda: Crustacea: Copepoda) revisited - morphology suggests a Palearctic origin. European Journal of Taxonomy 750: 1-28. https://doi.org/10.5852/ejt.2021.750.1357

\section{Introduction}

The biogeographic term 'Macaronesia' commonly refers to a region encompassing five archipelagos in the Northeast Atlantic: Azores, Madeira, Selvagens, Canaries and Cabo Verde (Triantis et al. 2010; Fernández-Palacios et al. 2011; but see Freitas et al. 2019 for a reappraisal of the biogeographic relations of Cabo Verde to Macaronesia vs Western Africa). The old age of the currently emergent islands (Azores 0.25-8.12 My, Madeira 4.6-14 My, Selvagens 27 My, Canaries 0.7-21 My, Cabo Verde 1-16 My), and a significantly older (Paleogene) age of the Paleo-Macaronesia archipelagos, as well as the proximity of the African continent, contributed to the high degree of diversification of the terrestrial arthropods in the region (Triantis et al. 2010; Fernández-Palacios et al. 2011; Boieiro et al. 2015). Also, the currently submerged paleo-islands could have facilitated stepping stone dispersal from both the Iberian Peninsula and North Africa to Macaronesia (Fernández-Palacios et al. 2011). Nonetheless, aquatic arthropods whose life cycle is entirely or partly dependent on freshwater environments seem to constitute only a minor part of the whole insular arthropod fauna. In the Azores, for example, the proportion of aquatic species (183) to all arthropods (2332) is only about 8\% (Raposeiro et al. 2012; Rego et al. 2015). Large and deep lakes do not occur in Macaronesia, and the Canaries have no permanent rivers, yet both the Azores (with caldera lakes, permanent rivers/creeks and mires) and Madeira (with numerous small rivers, streams and springs) offer diverse habitats to freshwater organisms (Defaye \& Dussart 1991; Raposeiro et al. 2012; Boieiro et al. 2015). In Macaronesia, the freshwater copepods are best known in the Azores: two calanoid, five (or eight) harpacticoid and 11 cyclopid species (including Eucyclops serrulatus (Fischer, 1851) and E. agiloides azorensis Defaye \& Dussart, 1991) have so far been reported from the archipelago (Lindberg 1962; Defaye \& Dussart 1991). In Madeira, only six cyclopid species, Halicyclops magniceps (Lilljeborg, 1853), E. serrulatus, Paracyclops chiltoni (G.M. Thomson, 1883), Tropocyclops prasinus (Fischer, 1860), Metacyclops minutus (Claus, 1863) and Acanthocyclops americanus (Marsh, 1893), and one putatively recently introduced diaptomid, Eudiaptomus gracilis (G.O. Sars, 1863), are known (Fischer 1860; Lindberg 1962; Vecchioni et al. 2020).

Eucyclops Claus, 1893 ( $\sim 120$ species and subspecies) is one of the largest genera in the Cyclopidae Rafinesque, 1815, yet except for a few species (e.g., the parasitic E. bathanalicola Boxshall \& Strong 2006 in Lake Tanganyika), the genus shows a surprisingly uniform limb segmentation and setation pattern. Diagnostic characters of the species and species groups (e.g., the serrulatus group and numerous subgenera currently defined by Alekseev 2019) overwhelmingly relate to the surface ornamentation of the body and appendages, and the body proportions (see Alekseev \& Defaye 2011; Mercado-Salas et al. 2016). Mouthpart characters have received less attention in the systematics of Eucyclops (but see Ishida 2002; Chang 2009; Tang \& Knott 2009). Morphometric features (e.g., relative length and robustness of the appendages of leg 5 , and the length and width proportion of the caudal rami), emphasized especially in the older taxonomic works, show significant intraspecific variation in some species (e.g., in E. serrulatus see Alekseev et al. 2006). Also, our poor understanding of the phylogenetic polarity of the morphological traits in the genus hinders a meaningful grouping of the species within Eucyclops (but see Gaponova \& Hołyńska 2019 for outgroup comparisons of some morphological characters).

In a project on the microcrustaceans of Algeria, conducted by the laboratory of Dr Amarouayache in 2012-2016, two of us (SG \& MA) found an Eucyclops in northeast Algeria (Tébessa and Souk-Ahras Provinces), which was identified as Eucyclops leschermoutouae Alekseev \& Defaye 2004 (Ghaouaci et al. 2017; Ghaouaci 2018). The Algerian Eucyclops shared several surface-ornamentation characters (on the A2 coxobasis, P4 intercoxal sclerite and coxopodite setae) with E. leschermoutouae (Balearic 
Islands: Mallorca), yet differed, among other things, in the length proportion of the terminal caudal setae VI and III. Comparisons of the paratypes of E. azorensis (originally named as E. agiloides azorensis) and additional specimens collected by one of us ( $\mathrm{LS}$ ) in Madeira helped to clarify the taxonomic status of the Algerian Eucyclops, and also revealed an interesting Macaronesian-North African distribution pattern in this species. Eucyclops azorensis was considered by Defaye \& Dussart (1991) as a subspecies of E. agiloides (G.O. Sars, 1909) originally described from East Africa. Therefore, we have also examined the types (from Lakes Victoria and Tanganyika) and additional specimens (from Lake Tanganyika) of E. agiloides, and redescribed the latter species as well. The morphology of E. agiloides remains poorly understood, although the species has been recorded in several sites in tropical Africa and Asia, and is currently associated with three other taxa (E. azorensis, E. roseus Ishida, 1997 and E. miracleae Alekseev, 2010) in subspecies relationships (Alekseev \& Defaye 2011; Alekseev 2019).

A better understanding of the taxonomic relationships of E. azorensis and E. agiloides has implications for both systematics of the genus and future studies on the origin of the freshwater cyclopid fauna in Macaronesia.

\section{Material and methods}

Collection information on the specimens examined is provided in the species descriptions. Unless otherwise stated, all specimens were fully dissected. Drawings were made using a camera lucida attached to Olympus BX 50 compound microscope. Telescoping somites were measured separately and summed for total body length (Koźmiński 1936). For scanning electron microscopy, whole specimens were dehydrated in graded acetone followed by hexamethyl-disilazane (HMDS) drying. Surface structures were investigated using a Hitachi S $3400 \mathrm{~N}$ (Museum and Institute of Zoology PAS, Warsaw) scanning electron microscope.

\section{Morphological abbreviations}

$\begin{array}{ll}\text { ae } & =\text { aesthetasc } \\ \text { caudal seta II } & =\text { anterolateral } \\ \text { caudal seta III } & =\text { posterolateral } \\ \text { caudal seta IV } & =\text { outer terminal } \\ \text { caudal seta V } & =\text { inner terminal } \\ \text { caudal seta VI } & =\text { terminal accessory } \\ \text { caudal seta VII } & =\text { dorsal } \\ \text { enp1-3 } & =\text { first to third endopodal segment } \\ \text { exp1-3 } & =\text { first to third exopodal segment } \\ \mathrm{P} 1-\mathrm{P} 4 & =\text { first to fourth swimming legs } \\ \mathrm{S} & =\text { seta } \\ \mathrm{sp} & =\text { spine }\end{array}$

\section{Repositories}

IZAN = Schmalhausen Institute of Zoology, Kiev

MIZ = Museum and Institute of Zoology PAS, Warsaw

MNHN $=$ Muséum national d'histoire naturelle, Paris

$\mathrm{NHM}=$ Natural History Museum, London 


\section{Results}

Phylum Arthropoda von Siebold, 1848

Subphylum Crustacea Brünnich, 1772

Class Hexanauplia Oakley, Wolfe, Lindgren \& Zaharoff, 2013

Subclass Copepoda Milne-Edwards, 1840

Order Cyclopoida Burmeister, 1835

Family Cyclopidae Rafinesque, 1815

Genus Eucyclops Claus, 1893

Eucyclops azorensis Defaye \& Dussart, 1991

Figs 1-6; Tables 1-3, 5

Eucyclops agiloides açorensis Defaye \& Dussart, 1991: 121-126, figs 2-14.

Eucyclops agiloides azorensis - Dussart \& Defaye 2006: 38. - Alekseev 2019 (part): 499-501.

Eucyclops leschermoutouae - Ghaouaci et al. 2017: 90. — Ghaouaci 2018: 64-67, figs 14-18.

\section{Material examined}

\section{Paratypes}

PORTUGAL • 2 우, 1 đ̊; Azores, Flores Island, nº15245, Ribeira Funda; 20 Oct. 1971; Th. Monod leg.; MNHN Cp. 611.

\section{Other material}

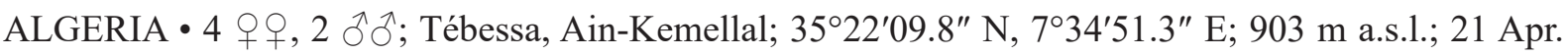
2016; S. Ghaouaci leg.; salinity 4-7 ppt; surface area 1 ha; temporary pool; MIZ 1/2021/8 to 1/2021/13 - 3 우우, 3 $\widehat{\jmath}$ (mounted for SEM); same collection data as for preceding; MIZ.

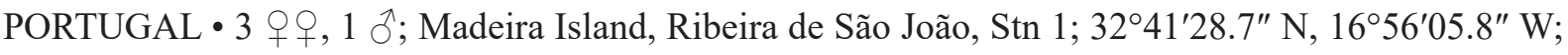
water depth $0.5 \mathrm{~m}$; 16 Sep. 2019 ; Ł. Sługocki leg.; water temp. $20.2^{\circ} \mathrm{C}$; pH 7.4; conductivity $88.1 \mu \mathrm{S} / \mathrm{cm}$; dissolved oxygen $9.46 \mathrm{mg} / \mathrm{L}$; stream, rock pool without macrophytes; transparent water; MIZ 1/2021/1 to 1/2021/4 • 1 क; Madeira Island, ponds SE hills, Stn 3; 32 $43^{\prime} 04.4^{\prime \prime} \mathrm{N}, 16^{\circ} 54^{\prime} 08.0^{\prime \prime}$ W; water depth $3 \mathrm{~m}$; 26. Sep. 2019; Ł. Sługocki leg.; water temp. $15^{\circ} \mathrm{C}$; pH 7.2; conductivity $55 \mu \mathrm{S} / \mathrm{cm}$; dissolved oxygen $5.34 \mathrm{mg} / \mathrm{L}$; old seminatural reservoir with macrophytes and algae; fresh water supply; MIZ 1/2021/5

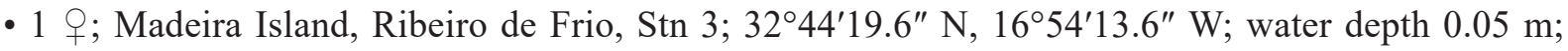
23 Sep. 2019; Ł. Sługocki leg.; water temp. $15.1^{\circ} \mathrm{C}$; pH 7.8; conductivity $130 \mu \mathrm{S} / \mathrm{cm}$; dissolved oxygen $8.98 \mathrm{mg} / \mathrm{L}$; stream, large rock pools with macrophytes and algae; MIZ 1/2021/6 • 1 क; Madeira Island, Ribeira de Machico, Stn 2; 3244'09.3" N, 16²7'57.9" W; water depth 0.1 m; 16 Sep. 2019; Ł. Sługocki leg.; water temp. $19.5^{\circ} \mathrm{C}$; $\mathrm{pH} 7.7$; conductivity $193 \mu \mathrm{S} / \mathrm{cm}$; dissolved oxygen $7.91 \mathrm{mg} / \mathrm{L}$; stream, small rock pools with dominance of algae and emergent macrophytes; MIZ 1/2021/7.

\section{Comparative material}

\section{Eucyclops serrulatus}

NETHERLANDS - 2 우 F Friesland, $4 \mathrm{~km}$ E of Leeuwarden, Tytsjerk municipality, park; $53^{\circ} 12^{\prime} \mathrm{N}$, 554' E; 19 Nov. 2008; M. Hołyńska \& P. Koomen leg.; pond shore; MIZ 1/2021/14 to 1/2021/15.

POLAND • 1 q; Mazovian Voivodeship, Milanówek; 5207.45’ N, 20³9.9’ E; 21 Aug. 2016; M. Hołyńska leg.; shallow pond with dense vegetation; MIZ 1/2021/18 • 1 +; West Pomeranian Voivodeship, Korytnica River; 5308.7' N, 1552.5' E; 2 Jun. 2016; M. Hołyńska leg.; river shore; MIZ 1/2021/19. 


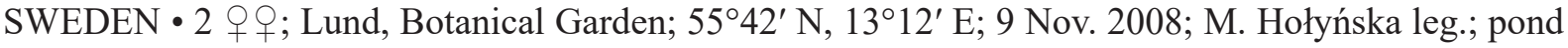
littoral; MIZ 1/2021/16 to 1/2021/17.

UKRAINE・2 9 + ; Danube; V.I. Monchenko Collection; IZAN.
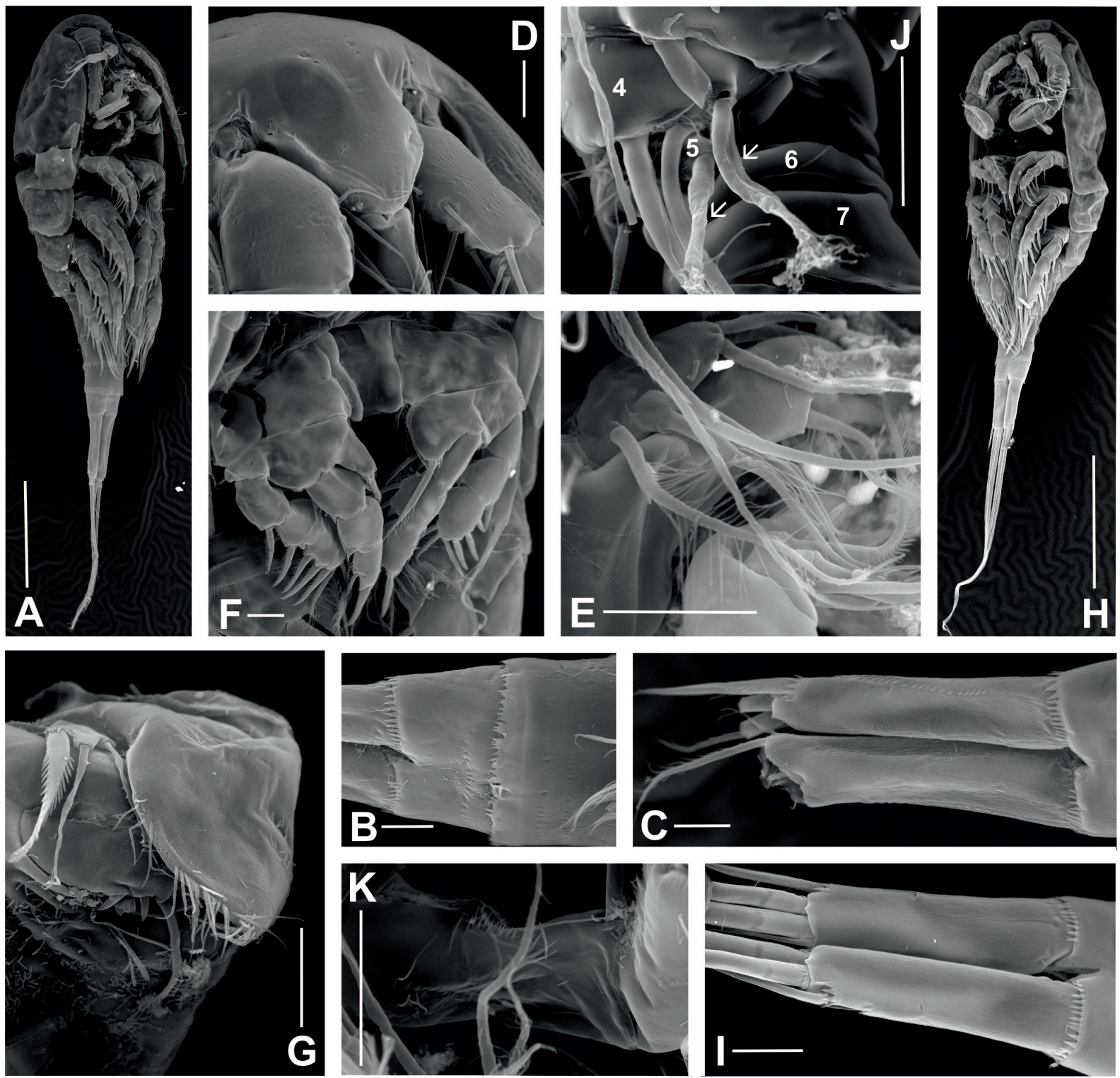

H
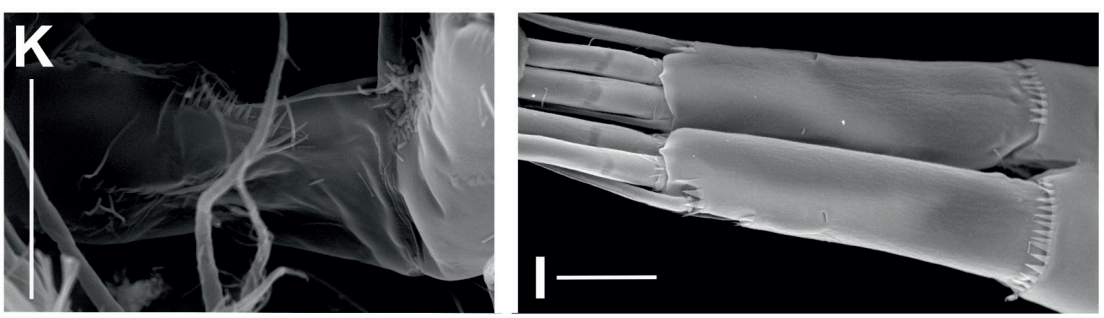

Fig. 1. Eucyclops azorensis Defaye \& Dussart, 1991 (Algeria, Ain-Kemellal; MIZ), SEM micrographs. A-G. . . H-K. O. A. Habitus, lateroventral view. B. Last two urosomal somites, ventral view - note the integumental ornamentation of shallow pits. C. Caudal rami, ventral view. D. Rostrum area of the cephalothorax and first antennulary segments. E. Maxillulary palp. F. Leg 1, frontal view. G. Leg 5 and leg 6. H. Habitus, ventral view. I. Caudal rami, ventral view - note the lack of 'Serra' on the lateral margin. J. Antennule, modified setae indicated by arrows on segments 4 and 5. K. Antennal coxobasis,

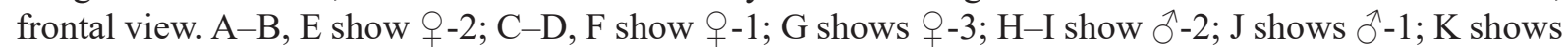
o-3. Scale bars: A, $\mathrm{H}=200 \mu \mathrm{m} ; \mathrm{B}-\mathrm{G}, \mathrm{I}-\mathrm{K}=20 \mu \mathrm{m}$. 


\section{Description}

Female (character states are shared by all specimens examined, unless stated otherwise) Habitus. Medium-sized Eucyclops, total body length ca $1 \mathrm{~mm}$ (Fig. 1A) - comparison of morphometric characters among Azorean, Madeiran and Algerian populations shown in Table 1. Prosomal and urosomal somites often adorned with shallow pits (Fig. 1B, D). Pediger 4 with fine hairs at posterolateral angle and small spinules on lateral margin (Figs 2A, 3A). Pediger 5 posterolaterally bearing long and robust hairs. Genital double-somite as long or slightly shorter than wide (Table 1). Single large copulatory pore oval shaped, located ventrally in anterior fifth of somite. Seminal receptacle as common in genus (cf. Fig. 8B), anterior and posterior parts short in length, posterior part wider than anterior. Anal operculum nearly straight, anal sinus with 1-1 longitudinal row of spinules. Posterior margin of anal somite with continuous row of spinules. Caudal rami 3.5-6.0 times as long as wide (Defaye \& Dussart 1991, see also Table 1 for interpopulation variation), no hairs on medial margin. 'Serra' (longitudinal row of spinules) on lateral margin extending from insertion of anterolateral (II) caudal seta to anterior $1 / 3-1 / 5$ of rami, more anterior spinules shifted to ventral surface and can be unnoticed in dorsal view (Fig. 1C). Spinules present at insertion of posterolateral (III) caudal seta. Single pore present on ventral surface near lateral margin, slightly posterior to midpoint of ramus. Seta III with fine setules medially and short spinules laterally. Dorsal (VII) caudal seta shorter, while terminal accessory (VI) seta longer than posterolateral caudal seta (Table 1).

ANTENNULE. 12-segmented, extending slightly beyond cephalothorax. Setation formula as common in genus: $1(\mathrm{I}-\mathrm{V}): 8 \mathrm{~s} ; 2$ (VI-VII): $4 \mathrm{~s} ; 3(\mathrm{VIII}): 2 \mathrm{~s} ; 4(\mathrm{IX}-\mathrm{XI}): 6 \mathrm{~s} ; 5(\mathrm{XII}-\mathrm{XIII}): 4 \mathrm{~s} ; 6(\mathrm{XIV}): 1 \mathrm{~s}+1 \mathrm{sp}$; 7(XV-XVI): $2 \mathrm{~s} ; 8(\mathrm{XVII}-\mathrm{XX}): 3 \mathrm{~s} ;$ 9(XXI-XXIII): $2 \mathrm{~s}+1$ ae; 10(XXIV): $2 \mathrm{~s} ; 11(\mathrm{XXV}): 2 \mathrm{~s}+1$ ae; 12(XXVI-XXVIII): $7 \mathrm{~s}+1$ ae. Aesthetasc on segment 9 short (Fig. 2B), 11-15 $\mu \mathrm{m}$ in length, not reaching beyond distal margin of segment. Aesthetasc on penultimate segment 30-34 $\mu \mathrm{m}$ long, almost reaching insertion of medial seta of segment 12 . Segments $10-12$ with smooth/finely serrate hyaline membrane. First antennulary segment bearing long spinules on ventral surface, spinules absent on other segments. Pits sometimes present on dorsal surface of more proximal antennulary segments (Fig. 1D). Terminal segment 4.3-6.3 times as long as wide.

AnTENna. Composed of coxobasis and three-segmented endopodite, and bearing 3, 1, 9 and 7 setae, respectively. Exopodite seta reaching distinctly beyond enp3, and bearing long setules proximally and short setules more distally (Fig. 2C). Coxobasis (Figs 2C, 3B) caudally ornamented with: hair-like spinules on proximolateral margin; longitudinal double rows near lateral margin, spinules in distal row sometimes distinctly smaller than those in proximal row; few small spinules near insertion of exopodal seta; transverse row at height of insertion of medial setae; oblique row below insertion of medial setae; and one or more groups of tiny spinules more proximally in medial half of segment. Spinules absent near distal margin. Frontal surface of antennal coxobasis (Figs 2D, 3C) with longitudinal row of spinules (6-15) along lateral margin and one or two oblique rows of long spinules and small spinules near proximal margin. Long hair-like spinules absent on distal and mediodistal margin.

MouthPaRTs. Labrum (cf. Fig. 8G). Distal margin with 9-12 teeth (some of those tiny), small spinules present on laterodistal lobes. Distal fringe hairs arranged in 1-1 group. Tiny spinules present on lateral margin at height of posterior end of epistoma in Madeiran and Algerian females - this character could not be verified in paratype specimens. Paragnaths with $4(3+1)$ medial claws, as common in Cyclopidae. Mandible (Fig. 2E) with palp bearing two long and one short setae. Near palp transverse row of long spinules and smaller spinules arranged in oval pattern present on anterior surface of coxal gnathobase. Maxillule setation as common in Cyclopidae. Maxillulary palp (Figs 1E, 2F) naked, with one proximal and three apical setae, lateral lobe bearing three setae. Armature of maxilla (cf. Fig. 9D-E) as common 
Table 1. Geographic variation of the female morphometric characters in Eucyclops azorensis Defaye \& Dussart, 1991. Data in bold are from the original description of the species (Defaye \& Dussart 1991). Numbers in subscript refer to the numbers of specimens measured.

\begin{tabular}{|c|c|c|c|c|c|c|}
\hline & \multicolumn{2}{|c|}{ Azores } & \multicolumn{2}{|c|}{ Madeira } & \multicolumn{2}{|c|}{ Algeria } \\
\hline & range & range & range & (mean) & range & (mean) \\
\hline 1. & $1005-1020_{2}$ & $780-1120_{51}$ & & & $804-1225$ & $(1050)_{6}$ \\
\hline 2. & $1.0_{2}$ & & & & $1.16-1.25$ & $(1.21)_{4}$ \\
\hline 3. & $0.82-0.91_{2}$ & & & & $0.93-0.98$ & $(0.95)_{4}$ \\
\hline 4. & $1.46-1.50_{2}$ & & & & $1.45-1.64$ & $(1.53)_{4}$ \\
\hline 5. & $1.0-1.11_{2}$ & & $1.0-1.06$ & $(1.02)_{3}$ & $1.05_{1}$ & \\
\hline 6. & $2.05-2.2_{2}$ & & $1.95-2.30$ & $(2.08)_{6}$ & $2.30-2.38_{2}$ & \\
\hline 7. & $2.1_{1}$ & & $2.3-3.1$ & $(2.69)_{5}$ & $2.65_{1}$ & \\
\hline 8. & $1.60-1.63_{2}$ & & $1.94-2.25$ & $(2.15)_{4}$ & $1.8_{1}$ & \\
\hline 9. & $4.50-4.54_{2}$ & $3.50-4.54_{48}$ & $3.65-4,20$ & $(3.99)_{5}$ & $4.0-5.9$ & $(4.79)_{7}$ \\
\hline 10. & $0.18-0.23_{2}$ & & $0.23-0.27$ & $(0.25)_{4}$ & $0.19-0.21$ & $(0.20)_{3}$ \\
\hline 11. & $0.22-0.23_{2}$ & & $0.20-0.23$ & $(0.22)_{3}$ & $0.21-0.27$ & $(0.24)_{4}$ \\
\hline 12. & $0.66_{1}$ & & $0.67-0.91$ & $(0.76)_{5}$ & $0.57-0.60_{2}$ & \\
\hline 13. & $1.15-1.34_{2}$ & 1.2 & $1.22-1.74$ & $(1.41)_{5}$ & $1.12-1.22$ & $(1.16)_{4}$ \\
\hline 14. & $6.3-7.6_{2}$ & & $6.0-8.2$ & $(6.6)_{5}$ & $8.4_{1}$ & \\
\hline 15. & $4.4_{1}$ & & $4.0-5.6$ & $(4.5)_{5}$ & $4.4-5.1_{2}$ & \\
\hline 16. & $0.69-0.73_{2}$ & 0.60 & $0.77-0.98$ & $(0.89)_{5}$ & $0.60-0.73$ & $(0.64)_{4}$ \\
\hline 17. & $3.8-4.1_{2}$ & & $3.82-4.42$ & $(4.2)_{5}$ & $4.2_{1}$ & \\
\hline 18. & $2.6_{1}$ & & $2.60-3.00$ & $(2.81)_{5}$ & $2.5-2.6_{2}$ & \\
\hline 19. & $0.56-0.60_{2}$ & & $0.54-0.72$ & $(0.64)_{5}$ & $0.50-0.6$ & $(0.55)_{4}$ \\
\hline 20. & $1.17_{1}$ & & $1.0-1.12$ & $(1.05)_{3}$ & $0.95-1.07$ & $(1.01)_{4}$ \\
\hline 21. & $2.20-2.23_{2}$ & $1.92-2.30$ & $1.96-2.26$ & $(2.14)_{6}$ & $2.32-2.44$ & $(2.36)_{4}$ \\
\hline 22. & $1.53-1.59_{2}$ & $1.23-1.50$ & $1.29-1.50$ & $(1.41)_{6}$ & $1.26-1.51$ & $(1.37)_{4}$ \\
\hline 23. & $1.07-1.12_{2}$ & & $0.97-1.11$ & $(1.02)_{6}$ & $0.97-1.13$ & $(1.04)_{4}$ \\
\hline
\end{tabular}

1. $=$ body length $(\mu \mathrm{m}) ; \mathbf{2 .}=$ cephalothorax, length $/$ width; $\mathbf{3 .}=$ genital double-somite, length $/$ width; $\mathbf{4} .=$ length of prosome/length of urosome; $\mathbf{5}$. = length of caudal seta V/length urosome; $\mathbf{6} .=\mathrm{P} 5$, length of medial spine/length of segment; 7. = P5, length of apical seta/length of segment; 8. = P5, length of lateral seta/length of segment; 9. = caudal ramus, length/width; 10. = length of caudal seta II/length of caudal ramus; 11. = distance of insertion of caudal seta II, measured from posterior end of ramus/length of caudal ramus; 12. = caudal setae, VII/III; 13. = caudal setae, VI/III; 14. = caudal setae, V/III; 15. = caudal setae, IV/III; 16. = length of caudal seta VI/length of caudal ramus; 17. = length of caudal seta V/length of caudal ramus; 18. = length of caudal seta IV/length of caudal ramus; 19. = length of caudal seta III/length of caudal ramus; 20. = P4, length of coxopodite seta/height of medial expansion of basipodite; 21. $=\mathrm{P} 4$ enp3, length $/$ width; 22. $=$ P4 enp3, medial terminal spine/lateral terminal spine; 23. $=\mathrm{P} 4$ enp3, medial terminal spine/segment length. 


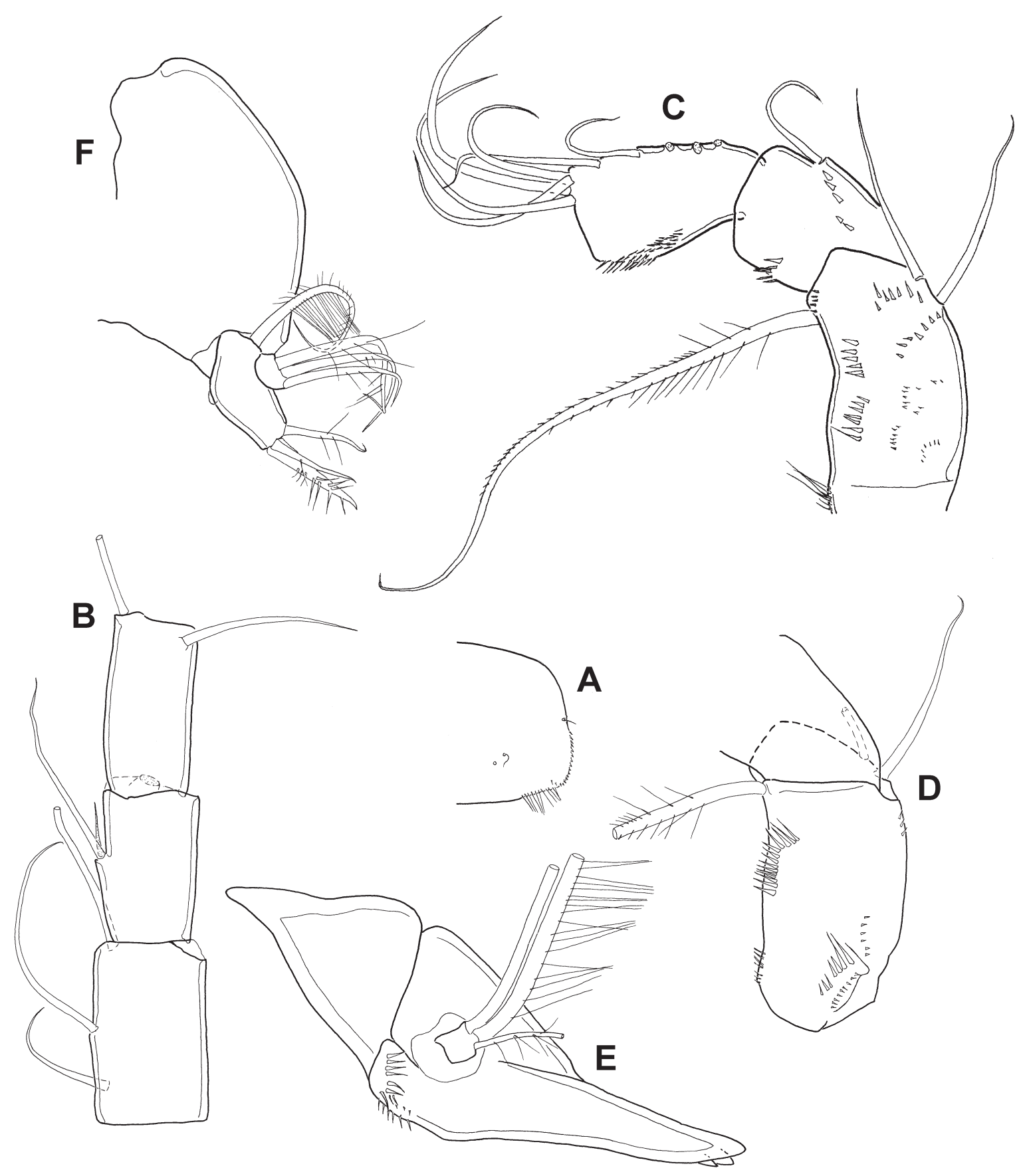

A

B-F

Fig. 2. Eucyclops azorensis Defaye \& Dussart, 1991, q (Azores, paratypes; MNHN Cp. 611). A. Pediger 4, lateral section, dorsal view. B. Antennulary segments $8-10$, dorsal surface - note short aesthetasc on segment 9. C. Antennal coxobasis and first and second endopodal segments, caudal view - note the suture line between basipodite and coxopodite. D. Antennal coxobasis, frontal view. E. Mandible. F. Maxillule. $\mathrm{A}, \mathrm{C}-\mathrm{F}$ show -1; B shows +2 . Scale bars: $\mathrm{A}-\mathrm{F}=50 \mu \mathrm{m}$. 

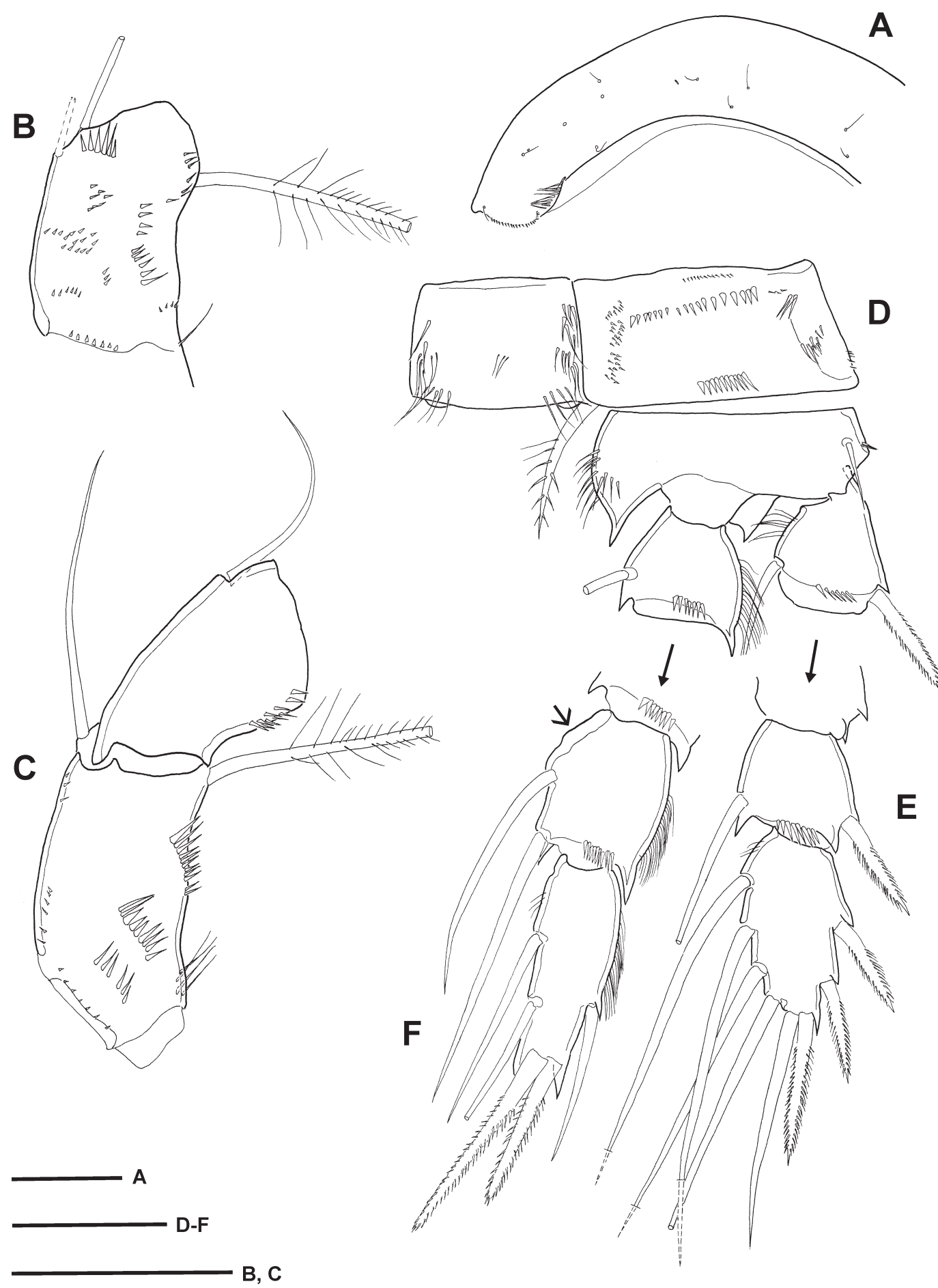

Fig. 3. Eucyclops azorensis Defaye \& Dussart, 1991, $q$ (Algeria, Ain-Kemellal; MIZ). A. Pediger 4 dorsal surface - note hairs at posterolateral angle. B. Antennal coxobasis, caudal view (inner medial seta broken). C. Antennal coxobasis and first endopodal segment, frontal view. D. Leg 4, protopodite and first exopodal and endopodal segments, caudal view. E. Leg 4, second and third exopodal segments, caudal view, (tips of some terminal setae were broken, seta length was reconstructed based on setae on the other side). F. Leg 4, second and third endopodal segments, caudal view - note thickened cuticle in inner proximal margin of second endopodite (arrow). A shows MIZ 1/2021/11; B-F show MIZ 1/2021/10. Scale bars: $\mathrm{A}-\mathrm{F}=50 \mu \mathrm{m}$. 


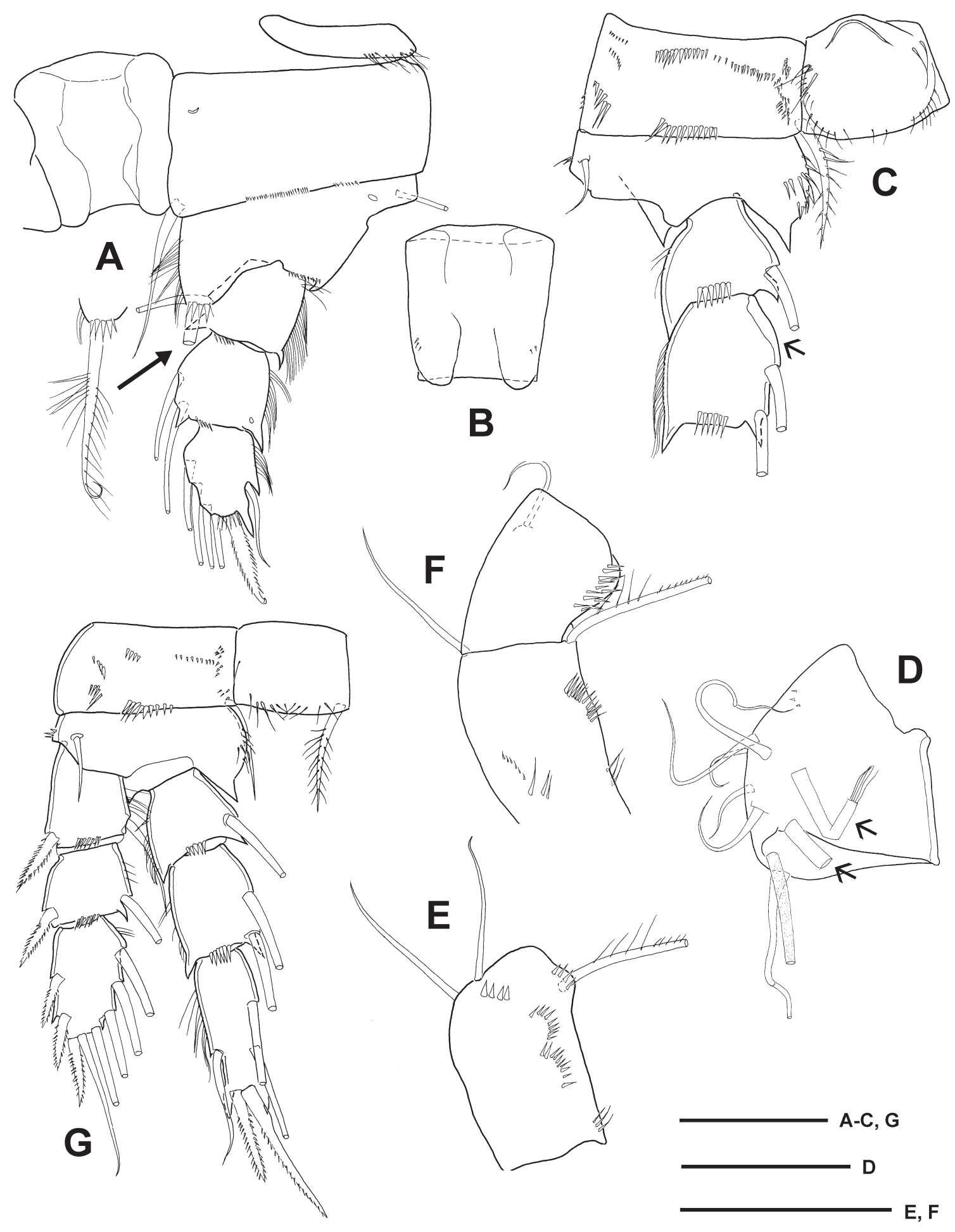

Fig. 4. Eucyclops azorensis Defaye \& Dussart, 1991 (Azores, paratypes; MNHN Cp. 611). A-C. ․ . D-G. O. A. Leg 1, frontal view - medial seta of basipodite is figured separately. B. Leg 1 intercoxal sclerite, frontal view. C. Leg 4, protopodite and first and second endopodal segments, caudal view - note thickened cuticle in inner proximal margin of second endopodite (arrow). D. First antennulary segment with two modified brush setae (arrows) and one aesthetasc (shaded), ventral view. E. Antennal coxobasis, caudal view. F. Antennal coxobasis and first endopodal segment, frontal view. G. Leg 4, caudal view.

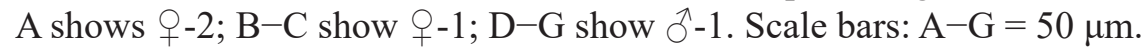


Table 2. Armature of legs 1-4 in Eucyclops azorensis Defaye \& Dussart, 1991. Spines are denoted by Roman numerals, setae by Arabic numerals. The armature on the lateral margin of any segment is given first, followed by the elements on the apical and medial margins.

\begin{tabular}{lcccc}
\hline & Coxopodite & Basipodite & Exopodite & Endopodite \\
\hline Leg 1 & $0-1$ & $1-\mathrm{I}$ & $\mathrm{I}-1 ; \mathrm{I}-1 ; \mathrm{II}-\mathrm{I}, 2-3$ & $0-1 ; 0-2 ; 1-\mathrm{I}, 1-3$ \\
Leg 2 & $0-1$ & $1-0$ & $\mathrm{I}-1 ; \mathrm{I}-1 ; \mathrm{III}-\mathrm{I}, 1-4$ & $0-1 ; 0-2 ; 1-\mathrm{I}, 1-3$ \\
Leg 3 & $0-1$ & $1-0$ & I-1; I-1; III-I,1-4 & $0-1 ; 0-2 ; 1-\mathrm{I}, 1-3$ \\
Leg 4 & $0-1$ & $1-0$ & I-1; I-1; II-I,1-4 & $0-1 ; 0-2 ; 1-\mathrm{II}-2$ \\
\hline
\end{tabular}

in Eucyclops, endopodite 2-segmented. Praecoxopodite and coxopodite separated on caudal surface and partially fused on frontal surface. Spinules distinctly large (cf. Fig. 9E, marked with arrow) or sometimes small near lateral margin of praecoxopodite on caudal surface. Armature of maxilliped (cf. Fig. 9F-G) as common in Eucyclops, arthrodial membrane between terminal endopodal segment and its medialmost seta failed to form. Spinules on caudal surface of basipodite arranged in two transverse rows. Small flaplike structure present on frontal surface near lateral margin of syncoxopodite (cf. Fig. 9G, marked with arrow); tiny spinules on edge of flap observed in Madeiran and Algerian specimens. Frontal surface of syncoxopodite sometimes (some Madeiran and Algerian specimens) adorned with one or two rows of fine spinules, near flap-like structure.

P1-P4. Setation as common in Eucyclops (Table 2). P1 intercoxal sclerite (Figs 1F, 4A-B) frontally naked or with few short spinules. P2-P4 intercoxal sclerites with spinules arranged in 1-1 group on frontal surface; spinules hair-like in P2 and short in P3 and P4. Intercoxal sclerite caudally bearing single transverse row of short spinules in middle of segment in P1, and hairlike spinules in two or three transverse rows in $\mathrm{P} 3-\mathrm{P} 4$. Intercoxal sclerite caudally naked or bearing one or two transverse rows of spinules (or hairs) in P2. Free margin of P4 intercoxal sclerite naked (Fig. 3D) or sparsely pilose (Fig. 4C) in middle section. P1-P3 coxopodite setae homonomously setulose (long and fine setules in P1, short and spinule-like setules in P2-P3). P4 coxopodite seta heteronomously setulose. Proximal setules sometimes distinctly longer than those more distally; medial (inner) margin with continuous setulation, while on lateral (outer) margin setules proximally missing or discontinuous ('gaps'), or sometimes continuous (Madeira, Ribeiro de Frio). Spinule pattern on caudal surface of P4 coxopodite (Figs 3D, 4C) as common in genus; number of spinules 8-14 in transverse row along distal margin, lateralmost spinule the longest one. Basipodite medially pilose in P1-P4 (Figs 3D, 4A, C), hairs long and fine in P1-P3, and shorter and thick in P4. Medial seta of P1 basipodite heteronomously setulose (Fig. 4A), bearing distinctly long setules on medial margin in proximal half, and shorter setules on lateral margin and more distal part of seta. With exception of P1 exp2, which is laterally pilose, all exopodal segments laterally naked (see P4 exopodite in Fig. 3D-E). Spatulate modification (relatively short and flattened setae, with short setules) of setae on terminal exopodal and endopodal segments of P2-P4 sometimes occur (Madeira, Machico). Cuticle of inner, proximal margin of $\mathrm{P} 4$ enp2 (Figs 3F, 4C, marked with arrow) thicker than in other parts of P4. None of setae of P4 enp3 reaching beyond tip of longer (medial) terminal spine.

P5 (Fig. 1G). One-segmented with three appendages. Medial spine strong and about twice as long as segment (Table 1). Apical seta nearly as long or slightly longer $(<1.5 \times)$ than medial spine, lateral seta slightly shorter but sometimes longer than medial spine. Small spinules present at insertion of medial spine.

Male (Fig. 1H)

Only those features are mentioned, which differ from the corresponding character states in female. 
Habitus. Total body length $0.69-0.95 \mathrm{~mm}$ (for morphometric data see Table 3). Pediger 4 and pediger 5 lacking posterolateral hairs. Length and width proportion of caudal rami 2.9-4.1. 'Serra' absent on caudal rami (Fig. 1I), yet spinules present at insertion of anterolateral and posterolateral caudal setae.

ANTENNULE (Figs 1J, 4D). 16-segmented. Setation formula of antennule: 1(I-V): $8 \mathrm{~s}$ (incl. 2 modified brush setae) + 1 ae (distal); 2(VI-VII): $4 \mathrm{~s}$ (incl. 1 brush seta); 3(VIII): $2 \mathrm{~s} \mathrm{(incl.} 1$ brush seta); 4(IX): $2 \mathrm{~s}$ (incl. 1 brush seta) +1 ae; 5(X): $2 \mathrm{~s} \mathrm{(incl.} 1$ brush seta); 6(XI); $2 \mathrm{~s} ; 7$ (XII): $2 \mathrm{~s} ; 8$ (XIII): $2 \mathrm{~s} ;$ 9(XIV): $1 \mathrm{~s}+$ $1 \mathrm{sp}+1$ ae; 10(XV) $2 \mathrm{~s} ; 11(\mathrm{XVI}) 2 \mathrm{~s} ; 12$ (XVII) $2 \mathrm{~s} ; 13$ (XVIII) $2 \mathrm{~s}+1$ ae; 14(XIX-XX): $2 \mathrm{~s}+1$ small cone +1 plate; $15(\mathrm{XXI}-\mathrm{XXIII}): 1 \mathrm{~s}+1$ small cone +2 plates +1 ae; 16 (XXIV-XXV and XXVI-XXVIII): $4 \mathrm{~s}+1$ ae and $7 \mathrm{~s}+1$ ae. Aesthetascs on segment 1, 4, and 9 distinctly long: $\sim 112 \mu \mathrm{m}, 85 \mu \mathrm{m}$, and $61 \mu \mathrm{m}$, respectively (measured in Madeiran male).

ANTENNA. Antennal coxobasis (Figs 1K, 4E-F): spinule ornamentation reduced on caudal surface in medial half of segment (Fig. 4E).

MouthPARTS. Maxillar praecoxopodite, caudal surface: spinules absent near lateral margin.

LEGS. P4 intercoxal sclerite naked frontally and sparsely pilose on caudal surface (Fig. 4G). Cuticle of inner, proximal margin of P4 enp2 not thicker than in other parts of P4. Setae of P4 enp3 usually not reaching beyond tip of longer (medial) terminal spine - in male from Madeira, setae reached slightly beyond tip of corresponding spine. Leg 6 with three appendages: medial spine 36-48 $\mu \mathrm{m}$ long, not reaching posterior margin of succeeding urosomal somite (Azores, Madeira) or extending slightly beyond it (Algeria); median seta 27-32 $\mu \mathrm{m}$; and lateral seta 34-40 $\mu \mathrm{m}$ (length proportions in Table 3).

\section{Geographic distribution (Fig. 5)}

Azores (widely distributed in Santa Maria, Terceira, Pico, Faial and Flores islands - see Defaye \& Dussart 1991), Madeira and North Africa (Algeria, Tébessa and Souk-Ahras Provinces).

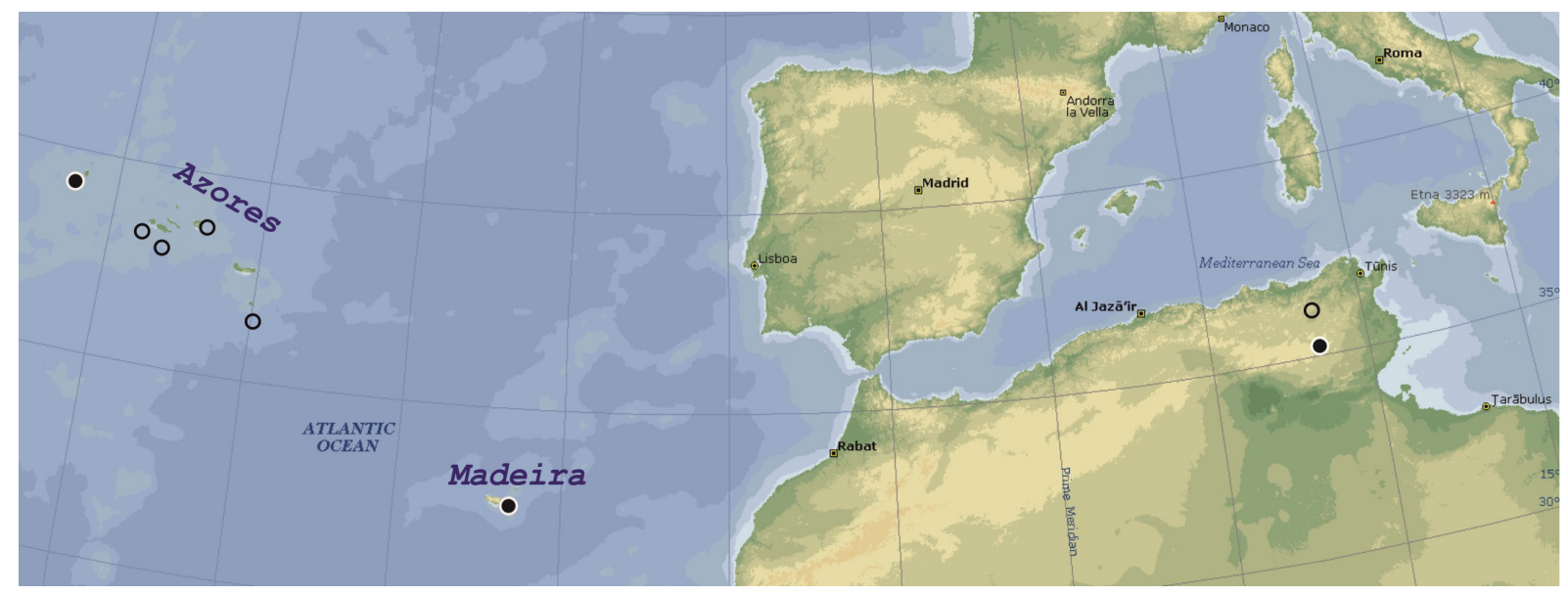

Fig. 5. Geographic distribution of Eucyclops azorensis Defaye \& Dussart, 1991. Filled black circles show occurrences verified by the authors, and open circles show records taken from literature (Defaye \& Dussart 1991; Ghaouaci et al. 2017; Ghaouaci 2018). 


\section{Habitats (Fig. 6)}

Fresh and brackish, both temporary and permanent waterbodies: rock pools in creek (river) bed, ponds, reservoirs, rivers, creek marshes, livestock water troughs, and fishponds.
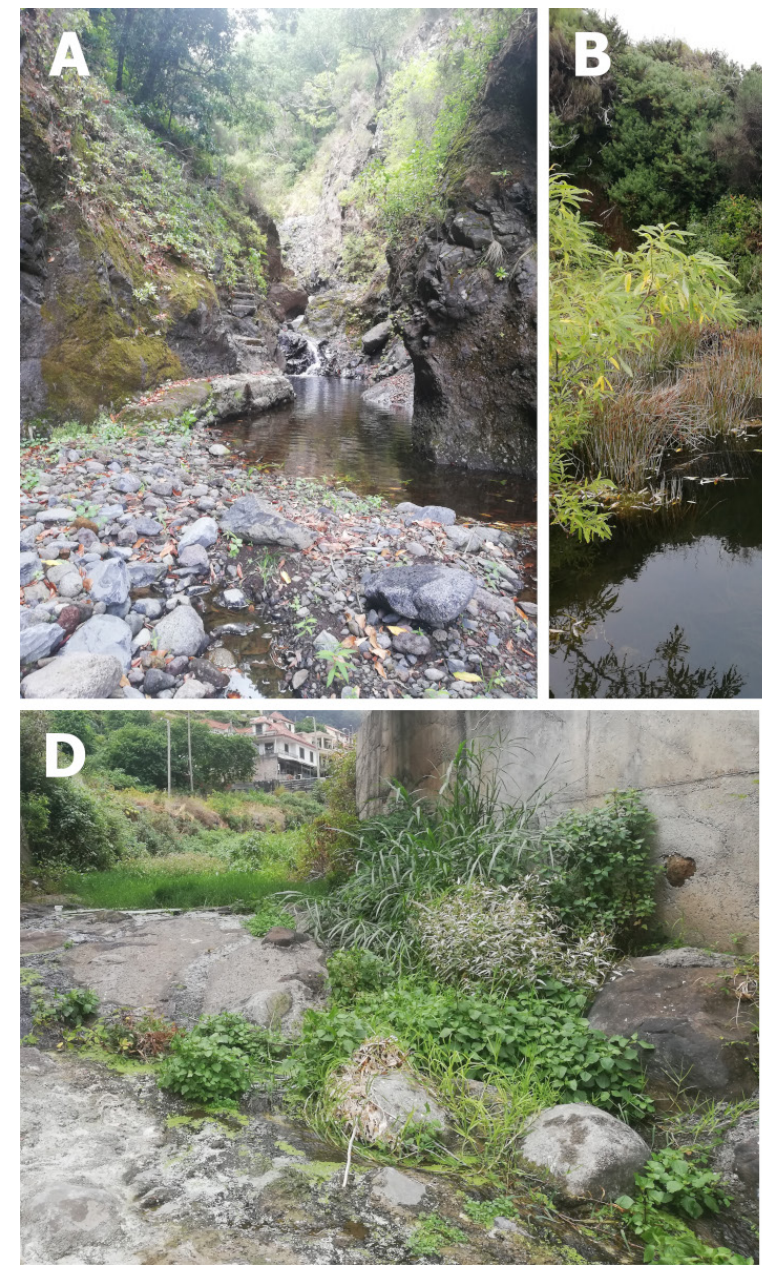
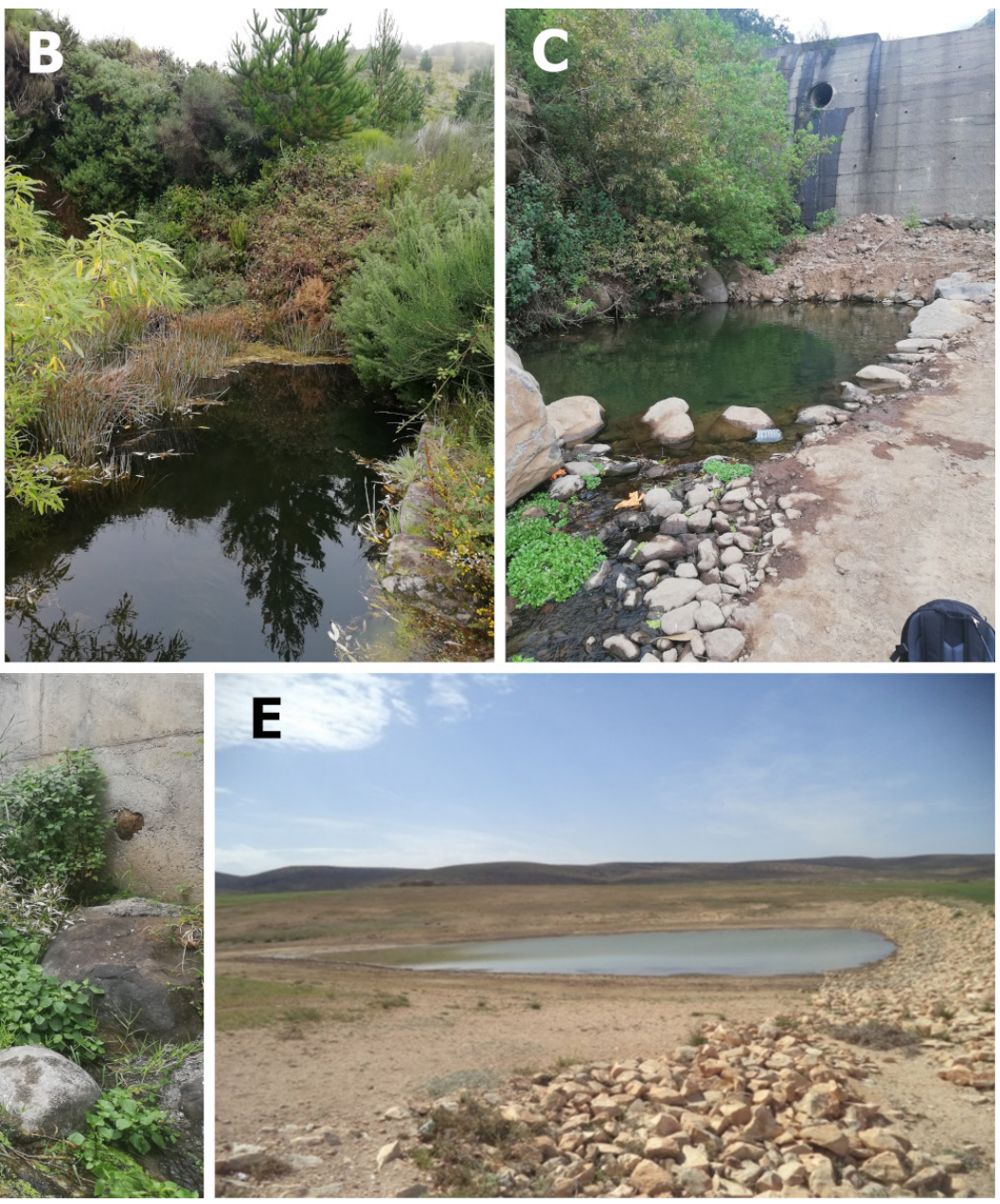

Fig. 6. Habitat variation in Eucyclops azorensis Defaye \& Dussart, 1991. A-D. Madeira, Portugal. E. Tébessa, Algeria. A. Ribeiro de Frio, flowing water. B. Seminatural freshwater pond. C. Ribeira de São João, nearly standing water. D. Ribeira de Machico, flowing water. E. Brackish pond at Ain Kemellal. 
Table 3. Morphometric characters of the male in Eucyclops azorensis Defaye \& Dussart, 1991. Data in bold are from the original description of the species: with the exception of the total body length, all indices were measured on the drawings provided by Defaye \& Dussart (1991). n/a $=$ non applicable.

\begin{tabular}{|c|c|c|c|c|c|}
\hline & \multicolumn{2}{|c|}{ Azores } & \multirow{2}{*}{ 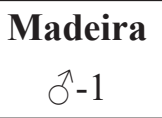 } & \multicolumn{2}{|c|}{ Algeria } \\
\hline & $\widehat{\jmath}-1$ & & & $\widehat{\jmath}-1$ & $\widehat{o}-2$ \\
\hline 1. & 825 & $690-890$ & & 950 & 935 \\
\hline 2. & 1.02 & & & 1.37 & 1.34 \\
\hline 3. & $\mathrm{n} / \mathrm{a}$ & & $\mathrm{n} / \mathrm{a}$ & $\mathrm{n} / \mathrm{a}$ & $\mathrm{n} / \mathrm{a}$ \\
\hline 4. & 1.79 & & & 1.61 & 1.55 \\
\hline 5. & 1.26 & & & 1.12 & \\
\hline 6. & 1.88 & 2.1 & 1.88 & 1.94 & 1.89 \\
\hline 7. & 2.41 & 1.78 & 2.9 & 1.78 & \\
\hline 8. & & 2.0 & 1.88 & & \\
\hline 9. & 3.32 & 3.42 & 2.92 & 4.09 & 3.33 \\
\hline 10. & 0.30 & 0.22 & 0.36 & 0.28 & 0.27 \\
\hline 11. & 0.26 & 0.29 & 0.26 & 0.27 & 0.26 \\
\hline 12. & 0.83 & 0.58 & 0.80 & 0.83 & \\
\hline 13. & 1.59 & 1.68 & 1.48 & 1.41 & 1.69 \\
\hline 14. & 9.5 & 9.28 & 7.19 & 8.30 & \\
\hline 15. & 6.0 & 5.68 & 4.19 & 5.10 & \\
\hline 16. & 0.89 & 1.02 & 1.14 & 0.69 & 1.04 \\
\hline 17. & 5.11 & 5.66 & 5.54 & 4.34 & \\
\hline 18. & 3.23 & 3.46 & 3.23 & 2.66 & \\
\hline 19. & 0.56 & 0.61 & 0.77 & 0.49 & 0.61 \\
\hline 20. & 1.06 & & 1.0 & 0.94 & 1.0 \\
\hline 21. & 2.35 & & 2.25 & 2.36 & 2.47 \\
\hline 22. & 1.50 & & 1.51 & 1.38 & 1.43 \\
\hline 23. & 1.09 & & 1.11 & 1.12 & 1.13 \\
\hline 24. & 0.80 & 0.71 & 0.89 & 0.56 & \\
\hline 25. & 1.00 & 1.04 & 0.97 & 0.71 & \\
\hline
\end{tabular}

1. $=$ body length $(\mu \mathrm{m}) ; \mathbf{2} .=$ cephalothorax, length $/$ width; $\mathbf{3 .}=$ genital double-somite, length $/$ width; $\mathbf{4} .=$ length of prosome/length of urosome; $\mathbf{5}$. = length of caudal seta $\mathrm{V} /$ length urosome; $\mathbf{6} .=\mathrm{P} 5$, length of medial spine/length of segment; 7. = P5, length of apical seta/length of segment; 8. = P5, length of lateral seta/length of segment; 9. = caudal ramus, length $/$ width; 10. = length of caudal seta II/length of caudal ramus; 11. = distance of insertion of caudal seta II, measured from posterior end of ramus/length of caudal ramus; 12. = caudal setae, VII/III; 13. = caudal setae, VI/III; 14. = caudal setae, V/III; 15. = caudal setae, IV/III; 16. = length of caudal seta VI/length of caudal ramus; 17. = length of caudal seta V/length of caudal ramus; 18. = length of caudal seta IV/length of caudal ramus; 19. = length of caudal seta III/length of caudal ramus; 20. = P4, length of coxopodite seta/height of medial expansion of basipodite; 21. = P4 enp3, length $/$ width; 22. $=$ P4 enp3, medial terminal spine/lateral terminal spine; 23. = P4 enp3, medial terminal spine/segment length; 24. = P6, length of median seta/length of medial spine; 25. $=\mathrm{P} 6$, length of lateral seta/length of medial spine. 
Eucyclops agiloides (G.O. Sars, 1909)

Figs 7-11; Tables 4-5

Cyclops agiloides G.O. Sars, 1909: 59, figs 183-188.

?Eucyclops agiloides - Alekseev \& Defaye 2011: 61, fig. 7. — Alekseev 2019: 499.

\section{Material examined}

\section{Holotype}

TANZANIA - + (undissected); Lake Victoria, Bukoba [Musila?] island (locality information is from Sars 1909); $1^{\circ} 19.9^{\prime}$ S, 31 $1^{\circ} 48.7^{\prime}$ E; 25(?) Apr. 1905; W.A. Cunnington, Third Tanganyika exped.; labelled as "Cyclops agiloides GOS, 269, Vict. Nyanza 437, Typical specimen, Type, +, 1909.6.24.303"; NHM.

\section{Paratypes}

TANZANIA • 1 \%; same collection data as for holotype; labelled as "Cyclops agiloides GOS, 437, 269 Vict. Nyanza, Syntype, Anatomy, ㅇ, 1909.6.24.300”; body parts were re-embedded in glycerine after solving the old (likely Hoyer) mounting medium in water; NHM.

ZAMBIA -1 (undissected); Lake Tanganyika, Niamkolo [Kumbula] island; $8^{\circ} 45.3^{\prime} \mathrm{S}, 31^{\circ} 5.9^{\prime} \mathrm{E}$; 19 Sep. 1904; W.A. Cunnington, Third Tanganyika exped.; labelled as "Cyclops agiloides GOS, 437, Tanganyika 97, Syntype,, , 1909.6.24.302"; NHM. Collection data were retrieved from Sars (1909), information on the Sars collection deposited in Oslo Zoological Museum (Åse Ingvild Wilhelmsen, in litt. 21 June 2019), and a map showing the route of the W.A. Cunnington Expedition 1904-1905 in Lake Tanganyika, published by Karlsson \& Karlsson (2019).

\section{Other material}

TANZANIA • 3 우; Lake Tanganyika, Kirando, river mouth; 7²1.6' S, 30³6.6' E; 1926; S. Pask leg.; identified as Eucyclops agiloides by R. Gurney, 1930 II 6 4-8; NHM. क -1 and $9-2$ were fully dissected, while in $9-3$ the antennule, antenna, the mouthparts and $\mathrm{P} 1$ were removed from the corpus and embedded in glycerol medium, and rest of the body remained in ethyl-alcohol.

\section{Comparative material}

Eucyclops roseus

CHINA - 2 우; Xinjiang-Uygur Autonomous Region, Bogda-Shan Mountain Range, Tianchi Lake; $43^{\circ} 53.2^{\prime}$ N, 88 $8^{\circ}$.95' E; 2000 m a.s.1.; 1 Jun.-1 Jul. 2011; E.S. Chertoprud, A.Y. Sinev and I. DimanteDeimantovica leg.; MIZ 1/2021/23, MIZ 1/2021/24.

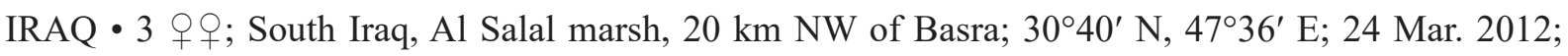
S.D. Salman and M. Hołyńska leg.; lake shore; MIZ 5/2014/1 to 5/2014/3 • 2 q $q$; Shatt al Arab River, Basra; 30³1' N, 4749' E; 21 Mar. 2012; S.D. Salman and M. Hołyńska leg.; MIZ 5/2014/4, MIZ $1 / 2021 / 21$.

RUSSIA 1 क ; Siberia, Yakutia, Kobiyanskiy Ulus County, Anga River, Melnikov Island; 63⒌ $51.9^{\prime}$ N, 127²7.05' E; 21 Aug. 2010; A.A. Kotov leg.; MIZ 1/2021/22.

SUDAN • 1 क; Khartoum State; Oct. 2012-Jul. 2013; G.M. Idris leg.; MIZ 1/2021/20.

UKRAINE $\bullet 2$ + 9 ; Arabatska Strilka [Arabat Spit], Strilkove Village; $45^{\circ} 54^{\prime}$ N, $34^{\circ} 52.8^{\prime}$ E; originally labelled as Eucyclops serrulatus; V.I. Monchenko collection; IZAN. 
Table 4. Morphometric characters of the female in Eucyclops agiloides (G.O. Sars,1909). * Length of telescoping somites could not be measured separately; therefore, the total body length was measured as the sum of the length of the prosome and urosome. K-1, K-2 and K-3 refer to $q-1, q-2$ and $q-3$ from Kirando, respectively.

\begin{tabular}{|c|c|c|c|c|c|c|}
\hline & \multicolumn{2}{|c|}{ Lake Victoria } & \multicolumn{4}{|c|}{ Lake Tanganyika } \\
\hline & holotype & paratype-1 & paratype-2 & K-1 & K-2 & K-3 \\
\hline 1. & $870 *$ & & $950 *$ & 1060 & $920 *$ & 1020 \\
\hline 2. & & & & 1.28 & & 1.32 \\
\hline 3. & 0.88 & & & 1.0 & 0.92 & 0.88 \\
\hline 4. & 1.49 & & 1.97 & 1.49 & & 1.52 \\
\hline 5. & & & & 1.04 & 1.01 & 0.96 \\
\hline 6. & & 1.69 & & & 1.65 & \\
\hline 7. & & 2.31 & & & 3.82 & \\
\hline 8. & & 1.56 & & & 1.55 & \\
\hline 9. & 4.11 & & & 6.00 & 5.89 & 5.57 \\
\hline 10. & 0.28 & & & 0.18 & & 0.19 \\
\hline 11. & 0.28 & 0.23 & & 0.20 & & 0.21 \\
\hline 12. & & & & & & 0.77 \\
\hline 13. & 1.89 & 1.44 & & 1.35 & 1.36 & 1.17 \\
\hline 14. & & & & 8.18 & 7.15 & 6.86 \\
\hline 15. & 5.21 & & & 5.23 & 4.68 & 4.48 \\
\hline 16. & 0.97 & 0.89 & & 0.59 & 0.60 & 0.51 \\
\hline 17. & & & & 3.33 & 3.17 & 2.98 \\
\hline 18. & 2.67 & & & 2.13 & 2.08 & 1.94 \\
\hline 19. & 0.51 & 0.59 & & 0.41 & 0.44 & 0.43 \\
\hline 20. & & & & 1.16 & 1.29 & \\
\hline 21. & & 2.21 & & 2.36 & 2.42 & \\
\hline 22. & & 1.37 & & 1.50 & 1.43 & \\
\hline 23. & & 1.06 & & 1.02 & 1.03 & \\
\hline
\end{tabular}

1. $=$ body length $(\mu \mathrm{m}) ; \mathbf{2} .=$ cephalothorax, length $/$ width; $\mathbf{3 .}=$ genital double-somite, length $/$ width; $\mathbf{4} .=$ length of prosome/length of urosome; $\mathbf{5}$. = length of caudal seta V/length urosome; $\mathbf{6} .=\mathrm{P} 5$, length of medial spine $/$ length of segment; 7. = P5, length of apical seta/length of segment; 8. = P5, length of lateral seta/length of segment; 9. = caudal ramus, length $/$ width; 10. = length of caudal seta II/length of caudal ramus; 11. = distance of insertion of caudal seta II, measured from posterior end of ramus/length of caudal ramus; 12. = caudal setae, VII/III; 13. = caudal setae, VI/III; 14. = caudal setae, V/III; 15. = caudal setae, IV/III; 16. = length of caudal seta VI/length of caudal ramus; 17. = length of caudal seta $\mathrm{V} /$ length of caudal ramus; 18. = length of caudal seta IV/length of caudal ramus; 19. = length of caudal seta III/length of caudal ramus; 20. $=$ P4, length of coxopodite seta/height of medial expansion of basipodite; 21. $=\mathrm{P} 4 \mathrm{enp} 3$, length $/$ width; 22. $=\mathrm{P} 4 \mathrm{enp} 3$, medial terminal spine $/$ lateral terminal spine; 23. $=\mathrm{P} 4$ enp3, medial terminal spine/segment length. 


\section{Description}

\section{Female}

HaBiTUs. Total body length $0.9-1.1 \mathrm{~mm}$ (for morphometric characters see Table 4). Pediger 4 and pediger 5 posterolaterally bearing long fine hairs and thick (spinule-like) hairs, respectively (Fig. 8A-B) - pilosity of pediger 4 could only be verified in females from Kirando, Lake Tanganyika. Genital double-somite (Fig. 8B) as long or slightly shorter than wide. Seminal receptacle as common in genus (Fig. 8B), anterior and posterior parts short in length, posterior part wider than anterior, single large copulatory pore in anterior fifth of somite. Anal operculum (Fig. 8D) nearly straight, anal sinus with longitudinal rows of hairs, posterior margin bearing continuous row of robust spinules. Caudal rami (Fig. 8D) 4.0-6.0 times as long as wide, no hairs on medial margin. Serra extending from insertion of anterolateral (II) caudal seta to anterior $1 / 5-1 / 6$ of rami. Seta II inserted in posterior $1 / 4-1 / 5$ of caudal ramus. Spinules present next to insertion of posterolateral (III) caudal seta. Relative length of caudal setae in Table 4.

ANTENNULE. 12-segmented, reaching middle length to posterior margin of pediger 2. Setation formula same as in E. azorensis. Aesthetasc (Fig. 7A) on segment 9 short, $\sim 12 \mu \mathrm{m}$ in length, not reaching distal margin of segment. Segments 10-12 with smooth (very finely serrate) hyaline membrane. First antennular segment bearing spinules on ventral surface, spinules absent on other segment. Terminal antennulary segment 5.0-7.1 times as long as wide.

Antenna. Composed of coxobasis and three-segmented endopodite, and bearing 3, 1, 9 and 7 setae, respectively. Exopodite seta reaching slightly (paratype, Lake Victoria) or distinctly (Kirando, Lake Tanganyika) beyond enp3, proximal setules can be similar in length or distinctly longer than setules in distal section of seta (Figs 7B, 8F). Caudal surface ornamentation of antennal coxobasis (Figs 7B, 8E) with same groups of spinules as those in E. azorensis in lateral half of segment, except for additional group of spinules next to distal margin (group marked with arrow in Fig. 7B). Medial half of segment with reduced ornamentation: few spinules sometimes present at height of insertion medial setae (Fig. 7B), or below setae (Fig. 8E). Frontal surface (Figs 7C, 8F) adorned with spinule-like hairs next to distal margin, hairs absent mediodistally, longitudinal/oblique row of spinules (8-13) along lateral margin, and oblique rows of large and small spinules near proximal margin.

MouthPaRTs. Labrum (Fig. 8G) with naked epistoma, distal fringe hairs arranged in two groups, teeth acute on distal rim, obtuse lateral lobes with tiny spinules. Paragnaths (Fig. $8 \mathrm{H}$ ) bearing longitudinal rows of hairs on outer (ventral) surface, longitudinal row of spinules more dorsally (indicated by dotted line in Fig. $8 \mathrm{H}$ ), mediodistal lobe with group of spinules. Four medial claw-like elements (three inserted close to each other and one inserted more distally) located slightly dorsally to hairs on outer (ventral) surface (not shown in figure). Long spinules present posterior to paragnaths. Mandible (Figs 7D, 9A) bearing two long and one short seta. Near palp transverse row of long spinules and smaller spinules arranged in row rather than oval pattern present on anterior surface of gnathobase. Maxillulary palp (Figs 7D, 9B-C) with few spinules arranged in discontinuous row/arc. Setation of maxilla (Fig. 9D-E) as common in Eucyclops, endopodite 2-segmented. Praecoxopodite and coxopodite separated on caudal surface and partially fused on frontal surface; short transverse row of spinules present near lateral margin on caudal surface (Fig. 9E, marked with arrow). Armature of maxilliped (Fig. 9F-G) as common in Eucyclops, arthrodial membrane between terminal endopodal segment and its medialmost seta failed to form. Basipodite with two rows of spinules on caudal surface. Tiny dents on free margin of flap-like structure (Fig. 9G, marked with arrow) sometimes present (maxilliped could be verified in specimens from Kirando, Lake Tanganyika).

P1-P4. Setation formula same as in E. azorensis (Table 2). P1 intercoxal sclerite (Fig. 9H) naked on both frontal and caudal surfaces in all specimens examined (one paratype from Lake Victoria and three females from Kirando, Lake Tanganyika). P2-P3 intercoxal sclerites (Fig. 10 B, D): hairs arranged in two groups present on frontal surface in both legs; transverse row of spinules present or absent on caudal 

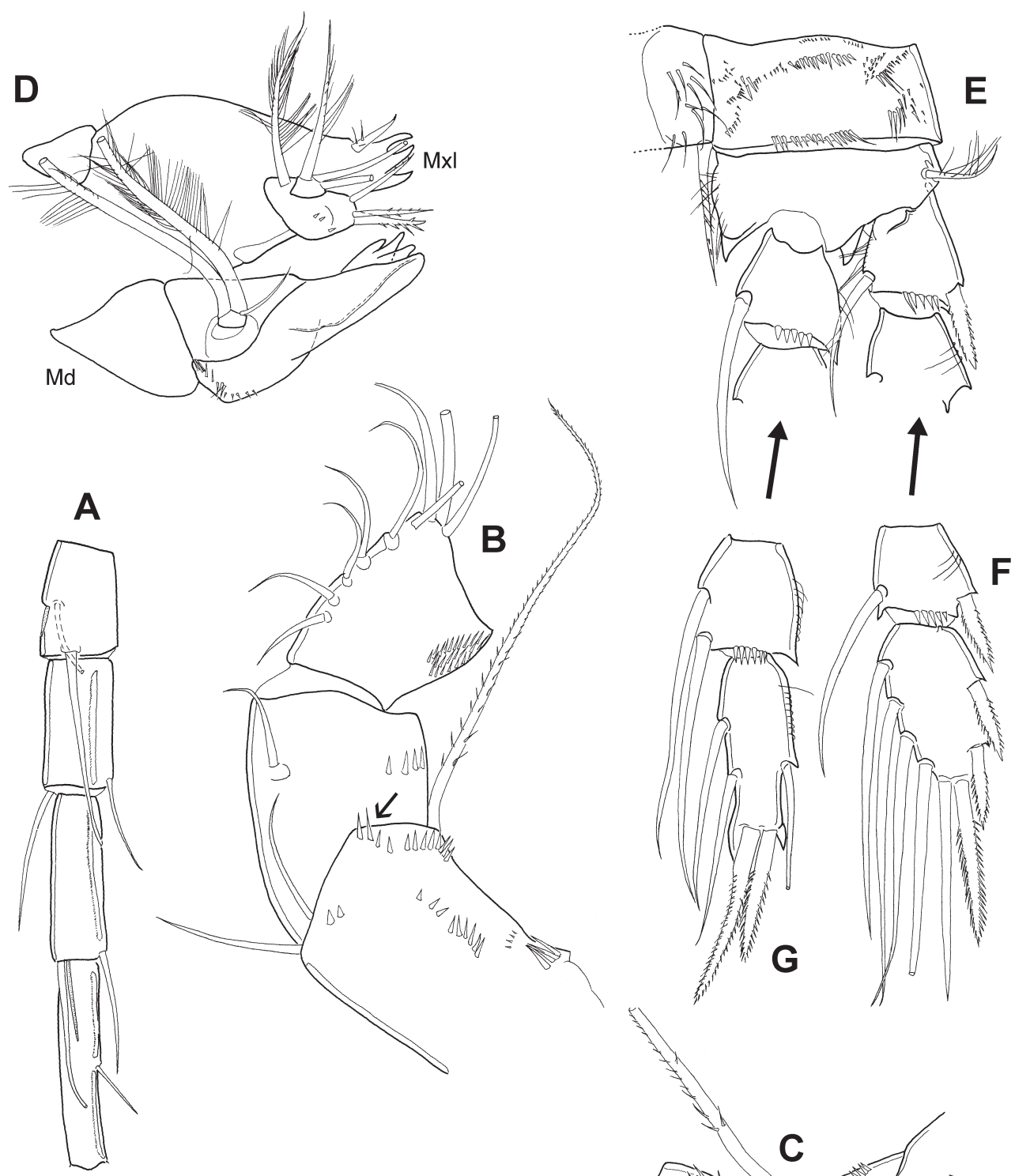

A, D-G

$B, C$

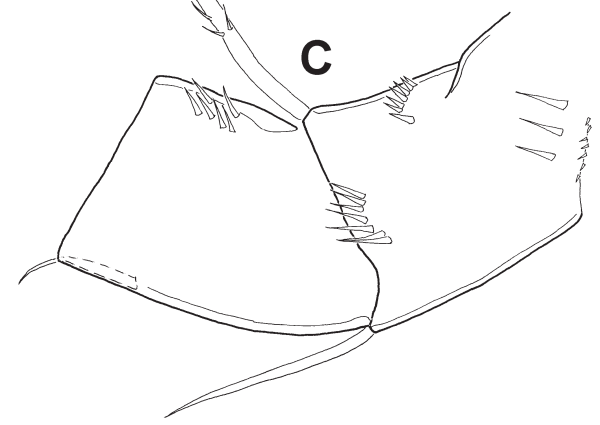

Fig. 7. Eucyclops agiloides (G.O. Sars, 1909) (Lake Victoria, paratype,, ; NHM). A. Antennulary segment 9-12, ventral surface (terminal setae of segment 12 are not figured). B. Antennal coxobasis and first and second endopodal segments, caudal view - note the group of spinules next to distal margin (arrow). C. Antennal coxobasis and first endopodal segment, frontal view. D. Mandible (Md) and maxillule (Mxl). E. Leg 4, protopodite and first exopodal and endopodal segments, caudal view. F. Leg 4, second and third exopodal segments, caudal view. G. Leg 4, second and third endopodal segments, caudal view. Scale bars: $A-G=50 \mu \mathrm{m}$. 


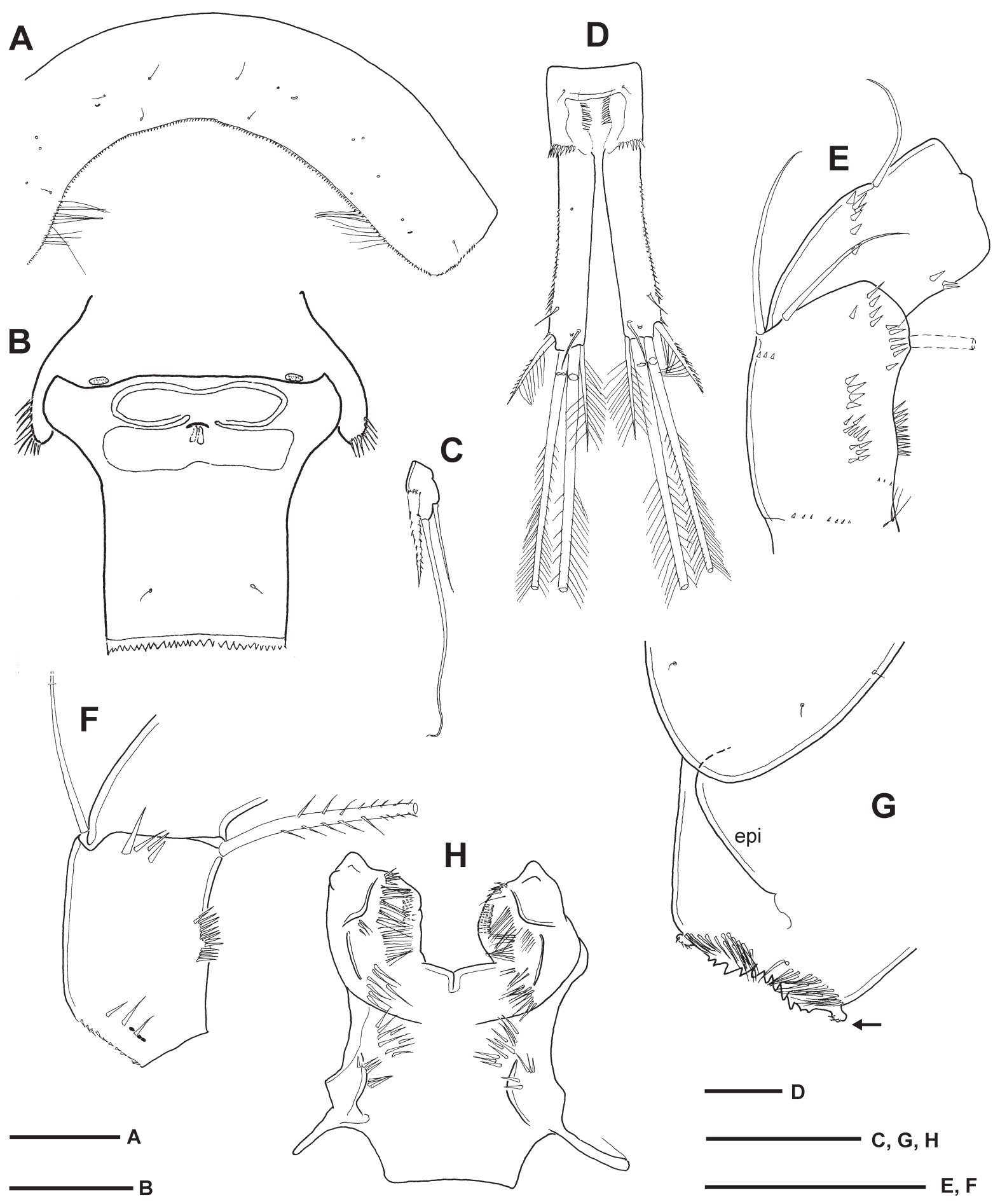

Fig. 8. Eucyclops agiloides (G.O. Sars,1909), q (Lake Tanganyika, Kirando; NHM). A. Pediger 4, dorsal view. B. Pediger 5 and genital double-somite (leg 5 is not figured), ventral view. C. Leg 5. D. Anal somite and caudal rami, dorsal view. E. Antennal coxobasis and first endopodal segment, caudal view. F. Antennal coxobasis, frontal view. G. Labrum - 'epi' shows epistoma, laterodistal lobe is indicated by arrow. H. Paragnaths, ventral view $(3+1$ medial claws inserted on opposite surface of both paragnaths are not figured). A, D-H show $+-1 ; \mathrm{B}-\mathrm{C}$ show - -2 . Scale bars: $\mathrm{A}-\mathrm{H}=50 \mu \mathrm{m}$. 


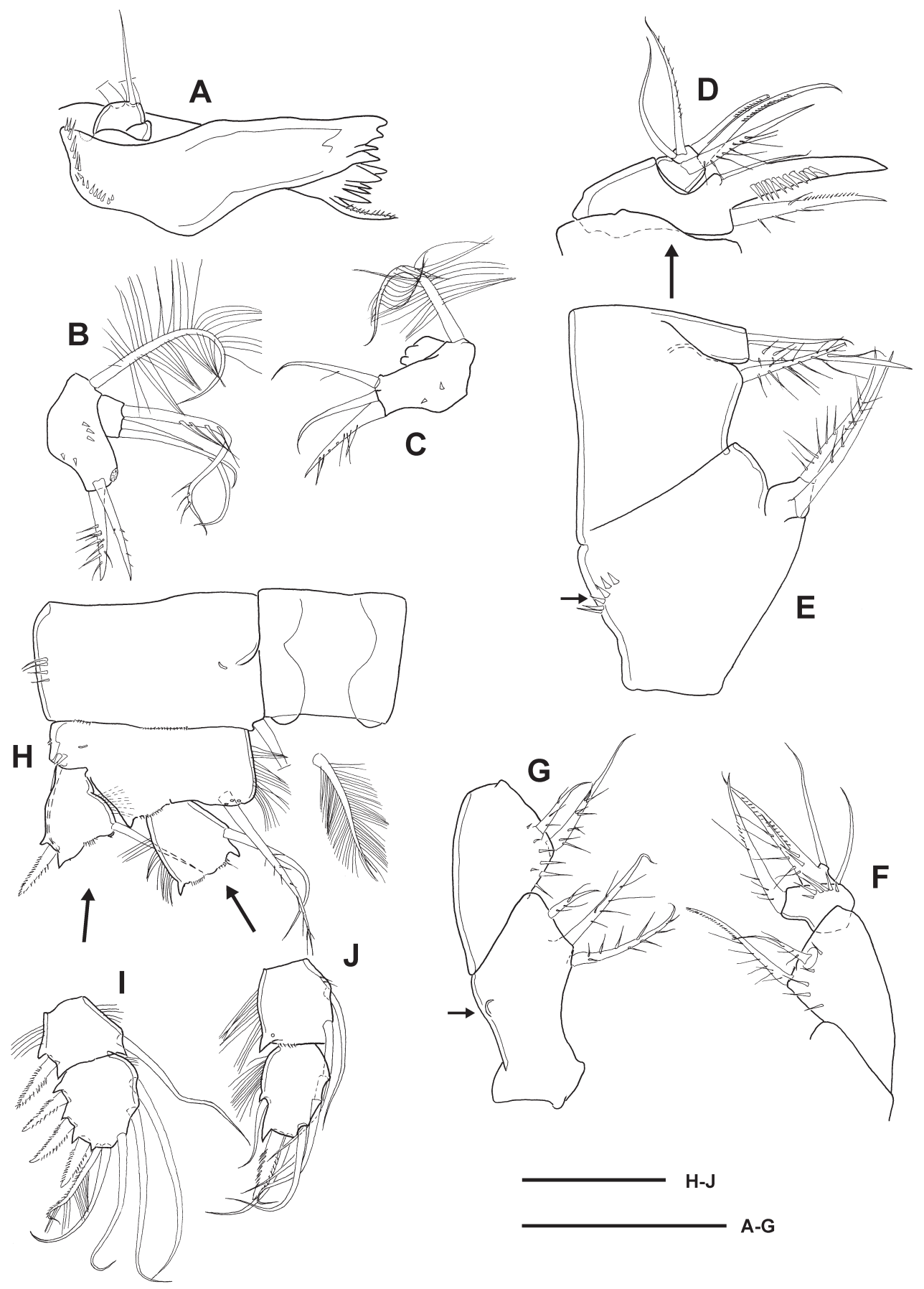

Fig. 9. Eucyclops agiloides (G.O. Sars,1909), $q$ (Lake Tanganyika, Kirando; NHM). A. Mandible, anterior view. B-C. Variation of the spinule ornamentation of the maxillulary palp. B. \&-1 (one apical seta is broken off). C. ㅇ-3. D. Maxillar basipodite and two-segmented endopodite, caudal view. E. Maxillar syncoxopodite, caudal view - note short transverse row of spinules near lateral margin (arrow). F. Maxilliped, basipodite and two-segmented endopodite, frontal view. G. Maxilliped, syncoxopodite and basipodite, frontal view - note the flap-like structure (arrow). H. Leg 1, protopodite and first exopodal and endopodal segments, frontal view (coxopodal seta is figured separately). I. Leg 1, second and third exopodal segments, frontal view. J. Leg 1 , second and third endopodal segments, frontal view. A shows

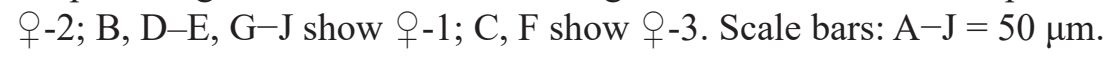




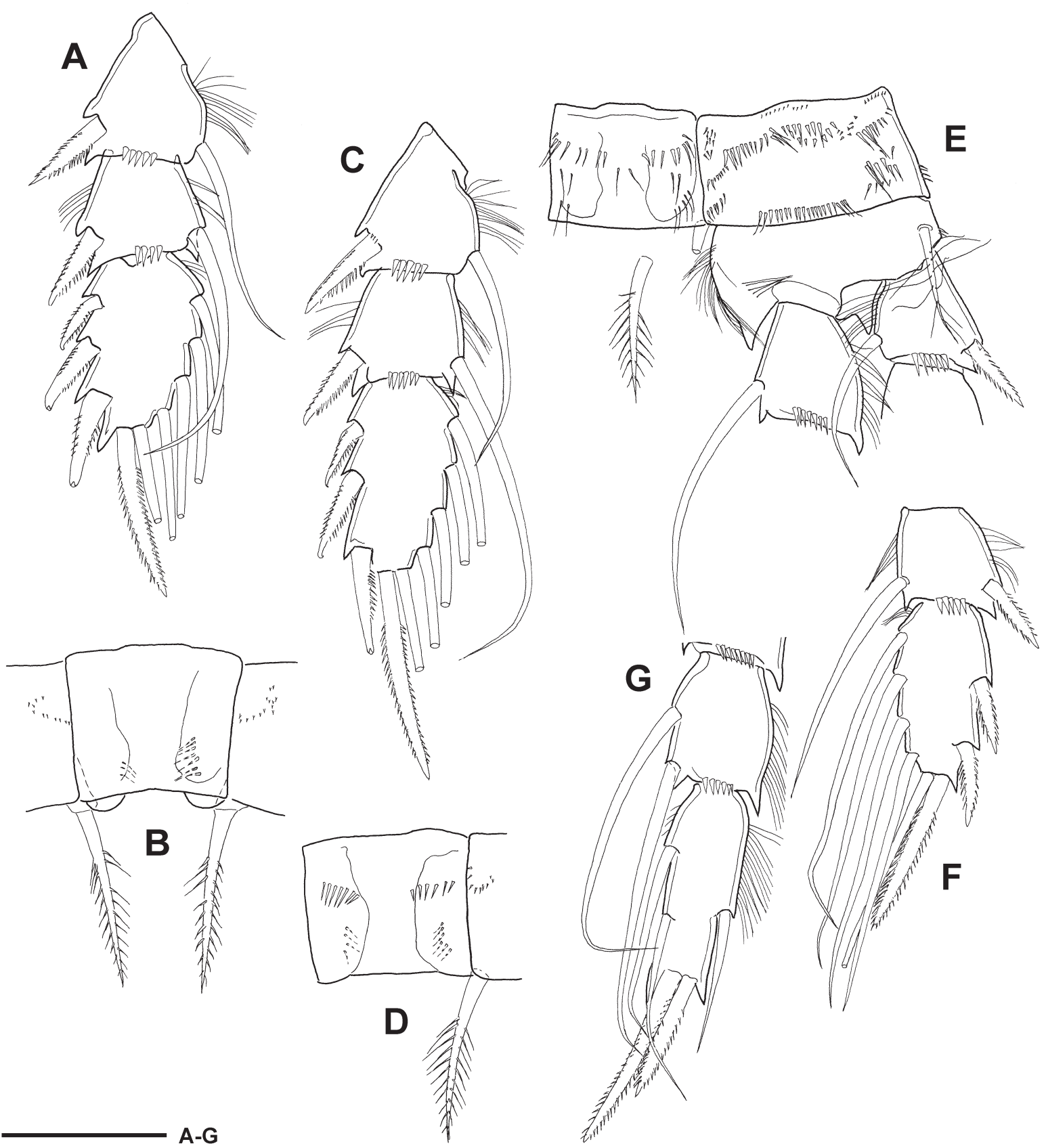

Fig. 10. Eucyclops agiloides (G.O. Sars,1909), ㅇ (Lake Tanganyika, Kirando; NHM). A. Leg 2 exopodite, caudal view. B. Leg 2 intercoxal sclerite, caudal view - ornamentation on the frontal surface is indicated by dotted line. C. Leg 3 exopodite, caudal view. D. Leg 3 intercoxal sclerite, caudal view ornamentation on the frontal surface is indicated by dotted line. E. Leg 4, protopodite and first exopodal and endopodal segments, caudal view (coxal seta is figured separately). F. Leg 4, second and third exopodal segments, caudal view. G. Leg 4, second and third endopodal segments, caudal view. All drawings show $9-1$. Scale bars: $\mathrm{A}-\mathrm{G}=50 \mu \mathrm{m}$. 
surface in P2 and present in P3. P4 intercoxal sclerite (Figs 7E, 10E) caudally bearing hairlike spinules in two (three) rows, free margin avoid of hairs in middle; frontal surface naked. Coxopodite setae with long and fine setules in P1, and short and thick setules in P2-P4 (Figs 9H, 10B, D-E). P4 coxopodite seta lacking setules in short proximal section on lateral margin (two $q$,, Kirando, Lake Tanganyika) - whole length (continuous) setulation shown in Sars (1909). Caudal surface ornamentation of P4 coxopodite (Figs 7E, 10E) as common in genus; number of spinules 20, 21 (two 우우, Kirando, Lake Tanganyika) in transverse row along distal margin. Medial expansion of basipodites pilose in P1-P4. Medial seta of P1 basipodite (Fig. 9H) with short setules, seta reaching beyond distal margin of enp2. Second exopodal segment laterally pilose, exp1 and exp3 laterally naked in P1-P4 (Figs 7E-F, 9H-I, 10A, C, E-F). P4 enp3 (Figs 7G, 10G) 2.2-2.4 times as long as wide, medial terminal spine 1.4-1.5 times as long as lateral spine, and about as long as segment (Table 4). None of setae of P4 enp3 reaching beyond tip of longer (medial) terminal spine.

P5 (Fig. 8C). One-segmented, with three appendages. Medial spine distinctly longer than segment (Table 4), small spinules present at insertion of spine. Apical seta 1.4 (paratype, L. Victoria) to 2.3 (Kirando, Lake Tanganyika) times as long as medial spine, lateral seta and medial spine subequal in length.

\section{Male \\ Unknown.}

\section{Geographic distribution and habitat preferences}

Eucyclops agiloides has been reported from various regions of Africa, Asia and even Eastern Europe: Lake Malawi (Alekseev \& Defaye 2011), Ethiopia (Defaye 1988), Nigeria (Boxshall \& Braide 1991), Northern Algeria (Hamaidi et al. 2010), Crimea, Lesser Caucasus and Talysh region (South Azerbaijan) (Monchenko 2003), China (Tai \& Chen $1979-$ E. agiloides was considered by these authors as a synonym of E. serrulatus), India (Kiefer 1939; Lindberg 1939; Dev Roy \& Venkataraman 2018), Sumatra and

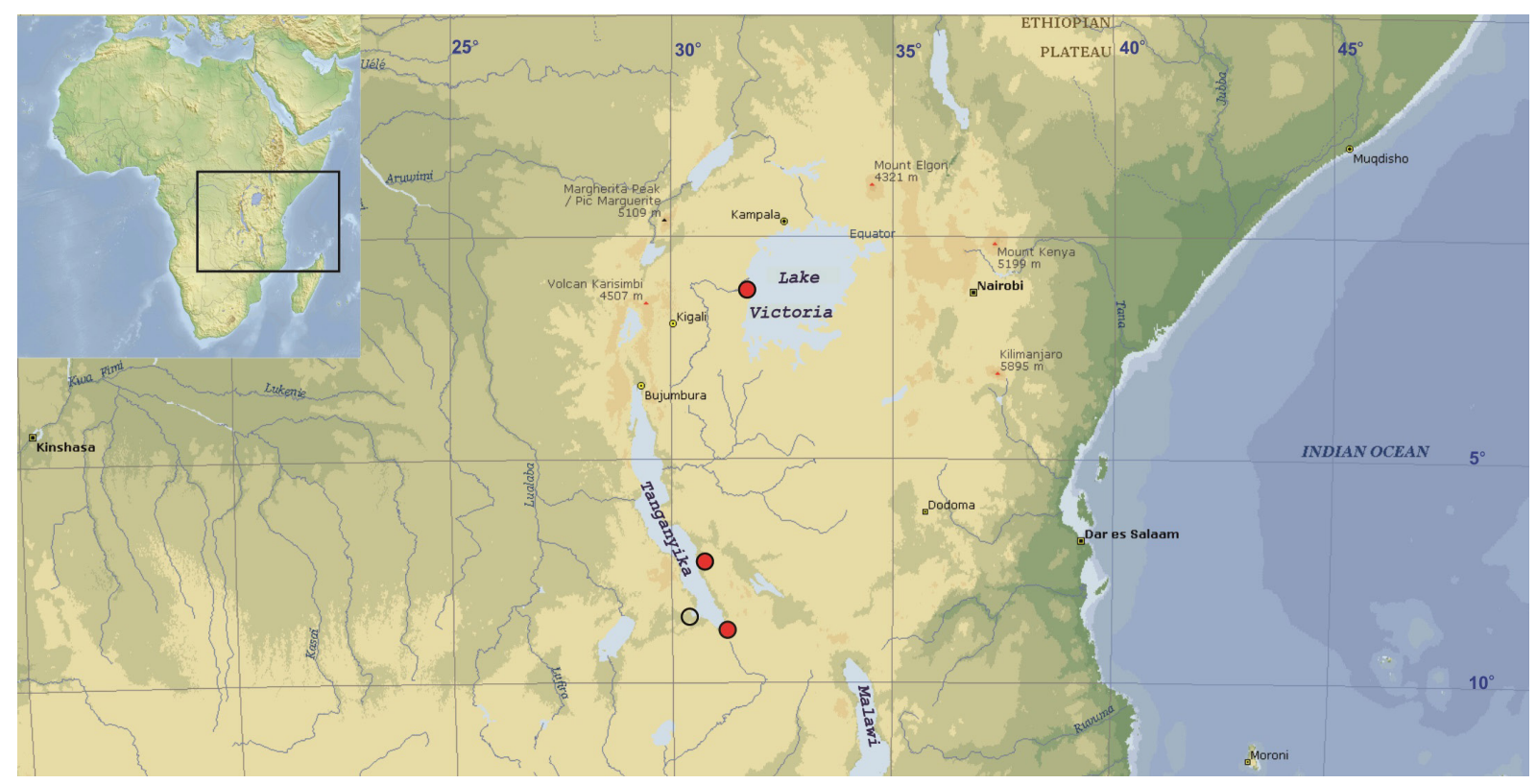

Fig. 11. Verified records of Eucyclops agiloides (G.O. Sars,1909). Filled red circles show occurrences verified by the authors, and open circle shows a record taken from the original description of the species (Sars 1909). 
Java (Kiefer 1933), and Borneo (Alekseev et al. 2016). Part of these records may refer to other taxa (e.g., E. roseus), and the geographic distribution of the species is still poorly understood (Fig. 11 shows only the verified records). The same holds true for the habitat preferences of E. agiloides. The specimens examined here were collected in large lakes and a river mouth in Lake Tanganyika, yet precise information on the collection sites is missing.

\section{Discussion}

Defaye \& Dussart (1991) described a Eucyclops from the Azores under the name E. agiloides azorensis. They noted that the new subspecies was morphologically identical with the cyclopid identified by Lindberg (1962) as Eucyclops serrulatus in the archipelago (São Miguel, Santa Maria, Pico, and Flores Islands). Defaye \& Dussart (1991) argued for a close relationship between the Azorean Eucyclops and African E. agiloides, based on a few characters that showed similar states (short 'Serra' of caudal rami; slender medial spine of leg 5; lack of aesthetasc on the $9^{\text {th }}$ antennulary segment; smooth hyaline membrane on $10^{\text {th }}$ to $12^{\text {th }}$ antennulary segment; and length and width proportion of terminal antennulary segment 7) in these two taxa, but different in E. serrulatus. Later studies (Alekseev et al. 2006; Alekseev \& Defaye 2011), however, revealed considerable variation in the morphology of the P5 medial spine in E. serrulatus, while variation in the extension of 'Serra' of the caudal rami in E. azorensis is documented herein (see Results). The aesthetasc on the $9^{\text {th }}$ antennulary segment, albeit relatively small and sometimes not easy to notice, does occur in both E. azorensis and E. agiloides (Figs 2B, 7A). 'Smoothness' of the hyaline membrane on the $10^{\text {th }}$ to $12^{\text {th }}$ antennulary segment is an elusive character, as it may depend on the microscope magnification applied. The length and width proportion of the terminal antennulary segment shows significant intraspecific variation and overlap between species (Table 5), although E. serrulatus indeed has a range with somewhat higher values in comparison to E. azorensis and E. agiloides.

Understanding of the taxonomic relationships of the Azorean Eucyclops has also been impeded by the relatively poor knowledge of the morphology of E. agiloides sensu stricto. Sars (1909) originally described the species from East Africa (Lakes Victoria and Tanganyika), and since then E. agiloides has been reported from several regions in Africa, (sub)tropical Asia and southeast Europe (for more details see 'Geographic distribution' of the species in the Results). Alekseev \& Defaye (2011) provided a short diagnosis and a few drawings of $E$. agiloides, based on specimen(s?) from Lake Malawi, mistakenly considered as the type locality. The lateral hair ornamentation of P4 exopodite (exp1-exp3 are pilose) and the presence of hairs in the full width of the free margin of P4 intercoxal sclerite (see Alekseev \& Defaye 2011: fig. 7b), however, might indicate that at least the fourth leg illustrated there belongs to E. roseus rather than to E. agiloides sensu Sars (cf. Figs 7E-F, 10E-F, and Table 5). In that same paper Alekseev and Defaye changed the taxonomic rank of E. roseus (subtropical and temperate Asia, East Africa and southeast Europe) and E. miracleae (Spain) from species to subspecies (see Alekseev \& Defaye 2011: 63). This decision has been confirmed in a current publication of Alekseev (2019), in which he listed four subspecies of E. agiloides (E. a. agiloides, E. a. roseus, E. a. miracleae and E. a. azorenis).

In Table 5 we compare 14 characters in the females of four taxa (E. serrulatus, E. azorensis, E. agiloides and $E$. roseus) to infer the taxonomic affinity of E. azorensis. Two character states (see character 4 in E. azorensis and character 6 in E. agiloides) occur in one species only. Characters 13 and 14 are intraspecifically variable and largely overlap between species; therefore, they are not informative of the morphological relationships of these taxa. Character 2 (presence/absence of spinules at height of the medial setae on the caudal surface of the antennal coxobasis) is an ambiguous character: the spinules are present (without variation) in E. serrulatus and E. azorensis, while the character is polymorphic in $E$. agiloides and $E$. roseus. Of the nine informative characters, six $(1,3,7,8,10,11)$ support a closer relationship between $E$. azorensis and E. serrulatus, while three $(5,9,12)$ are shared by $E$. azorensis and $E$. agiloides but different in E. serrulatus. Distribution of the characters selected here suggests that Azorean Eucyclops is not a subspecies of E. agiloides. Instead, it is morphologically closer to 
Table 5. Comparison of the diagnostic morphological characters in the female of Eucyclops azorensis Defaye \& Dussart, 1991 and the putative close relatives. Character states were verified in all dissected specimens listed in 'Material examined' and 'Comparative material' (see the species descriptions).

\begin{tabular}{|c|c|c|c|c|}
\hline & E. serrulatus & E. azorensis & E. agiloides & E. roseus \\
\hline $\begin{array}{l}\text { 1. A2 coxobasis caudal surface, } \\
\text { spinules near distal margin }\end{array}$ & absent & absent & present & present \\
\hline $\begin{array}{l}\text { 2. A2 coxobasis caudal surface, } \\
\text { spinules near insertion of medial setae }\end{array}$ & present & present & present/absent & present/absent \\
\hline $\begin{array}{l}\text { 3. A2 coxobasis caudal surface, } \\
\text { row/field starting at midpoint of } \\
\text { lateral margin }\end{array}$ & present & present & absent & present/absent \\
\hline $\begin{array}{l}\text { 4. A2 coxobasis frontal surface, } \\
\text { long spinules next to distal margin }\end{array}$ & present & $\begin{array}{l}\text { absent/pre- } \\
\text { sent }^{1}\end{array}$ & present & present \\
\hline $\begin{array}{l}\text { 5. A2 coxobasis frontal surface, } \\
\text { long spinules mediodistally }\end{array}$ & present/absent & absent & absent & present \\
\hline $\begin{array}{l}\text { 6. Mandible, ornamentation near palp, } \\
\text { spinules on anterior surface }\end{array}$ & oval pattern & oval pattern & row & oval pattern \\
\hline $\begin{array}{l}\text { 7. Maxillulary palp, } \\
\text { spinules }\end{array}$ & absent & absent & discont. row/arc & oval pattern \\
\hline $\begin{array}{l}\text { 8. P1 basipodite medial seta, } \\
\text { proximally, medial margin, setules }\end{array}$ & long & long & short & short \\
\hline $\begin{array}{l}\text { 9. P1 intercoxal sclerite frontal surface, } \\
\text { groups of spinules/hairs }\end{array}$ & present & absent/tiny & absent & present \\
\hline $\begin{array}{l}\text { 10. P1 intercoxal sclerite caudal surface, } \\
\text { transverse row of spinules }\end{array}$ & present/absent ${ }^{2}$ & present & absent & absent \\
\hline $\begin{array}{l}\text { 11. } \mathrm{P} 1, \mathrm{P} 2, \mathrm{P} 3, \mathrm{P} 4, \exp 1-2 \text {, } \\
\text { lateral pilosity }\end{array}$ & $\begin{array}{l}0-1 ; 0-0^{3} \\
0-0 ; 0-0\end{array}$ & $\begin{array}{l}0-1 ; 0-0 \\
0-0 ; 0-0\end{array}$ & $\begin{array}{l}0-1 ; 0-1 \\
0-1 ; 0-1\end{array}$ & $\begin{array}{l}1 / 0^{4}-1 ; 1-1 \\
1-1 ; 1-1\end{array}$ \\
\hline $\begin{array}{l}\text { 12. P4 intercoxal sclerite free margin, } \\
\text { hairs in middle section }\end{array}$ & present & absent/sparse & absent & present/absent \\
\hline $\begin{array}{l}\text { 13. A1 terminal segment, } \\
\text { length/width }\end{array}$ & $5.8-7.5$ & $4.3-6.3$ & $5.0-7.1$ & $4.9-6.9$ \\
\hline $\begin{array}{l}\text { 14. P4 coxopodite seta, } \\
\text { lateral margin, setulation }\end{array}$ & prox. abs./discont. & $\begin{array}{c}\text { prox. abs./ } \\
\text { discont./ cont. }{ }^{5}\end{array}$ & prox. abs./cont. & prox. abs./cont. \\
\hline
\end{tabular}

${ }^{1}=$ spinules are present in one female, Ribeira de São João, Madeira; ${ }^{2}=\mathrm{P} 1$ intercoxal sclerite is likely naked on the caudal surface (verified in frontal view) in two females from Poland; ${ }^{3}=$ P2 exp2 with lateral hairs in Alekseev \& Defaye 2011 (fig. 5b); ${ }^{4}=$ no hairs on P1 exp1 in one female, Anga River, Siberia; ${ }^{5}=$ continuous setulation in one female from Ribeiro de Frio, Madeira; abs. = absent; cont. = continuous; discont. = discontinuous (with 'gap'); prox. = proximally. ' 0 ' and ' 1 ' (character 11) code 'hairs absent' and 'hairs present', respectively. 
E. serrulatus. Eucyclops azorensis differs from E. serrulatus in a few features only: distal hairs are absent on the frontal surface of the antennal coxobasis (vs hairs present in E. serrulatus); P1 intercoxal sclerite is frontally naked or bearing just a few tiny spinules (vs spinules present in E. serrulatus); and hairs are absent/sparse in the middle section of the free margin of P4 intercoxal sclerite (vs whole width pilose in E. serrulatus). Nonetheless, a sister relationships between E. serrulatus (Palearctic, as far as Yenisey River in Siberia - Alekseev \& Defaye 2011), and E. azorensis (Azores, Madeira and North Africa) could only be confirmed after a thorough comparison of the Western Mediterranean forms, such as E. hadjebensis (Kiefer, 1926) from North Africa, E. albuferensis Alekseev 2008, E. romaniensis Alekseev 2010 and E. miracleae from continental Spain, and E. leschermoutouae from the Balearic Islands (Mallorca). With the exception of E. leschermoutouae all the other species mentioned above, unlike E. azorensis, possess hair-like spinules next to distal margin on the frontal surface of the antennal coxobasis (Alekseev \& Defaye 2004; Alekseev 2008, 2010). Eucyclops leschermoutouae differs from E. azorensis in the length proportion of caudal setae VI and III (seta VI/seta III $<1$ in E. leschermoutouae, while seta VI/seta III $>1$ in E. azorenis), and the relative length of the lateral terminal spine of P4 enp3 (nearly as long as P4 enp3 in E. leschermoutouae, vs distinctly shorter in E. azorensis) (comparisons were based on Alekseev \& Defaye 2004). Applying the subgeneric classification currently proposed by Alekseev (2019), Eucyclops azorensis would belong to the subgenus Speratocyclops Alekseev, 2019, while the morphologically close E. serrulatus and all the Western Mediterranean species mentioned above, with the exception of E. leschermoutouae, would be members of the subgenus Eucyclops s. str. We hesitate to accept such a grouping. The subgenera Speratocyclops and Eucyclops s. str. are distinguished from each other by a single character in fact (character 4 in Table 5). A natural classification should reflect the evolutionary relationships; therefore, it would be desirable to conduct a comprehensive analysis of the phylogenetic relationships, or at least to discuss the distribution of numerous characters within and outside the genus (outgroup comparisons), before proposing a subgeneric classification of Eucyclops.

Concerning the taxonomic position of E. roseus, the morphological differences between this taxon and E. agiloides in the surface ornamentation of the antennal coxobasis, mandible, maxillulary palp, P1 intercoxal sclerite and P1-P4 exopodites (Table 5: characters 5-7, 9 and 11), as well as the sympatric occurrence of these forms in Lake Victoria (Sars 1909; Ishida 1998), indicate a species, rather than subspecies, level differentiation between these taxa. Nevertheless, to corroborate this hypothesis more information on the intraspecific variation within E. agiloides in tropical Africa is definitely needed.

\section{Acknowledgements}

The authors thank Dr Laure Corbari and Dr Miranda Lowe, curators of the Muséum national d'histoire naturelle Paris and the Natural History Museum London, respectively, for loaning essential material for our studies. The assistance of Dr Magdalena Kowalewska-Groszkowska in the scanning electron microscopic investigations is very much appreciated. We thank Dr Ricardo Araújo, curator of the Museum of Natural History in Funchal (Madeira, Portugal), and Mr Juan Silva and Mr Alan Nóbrega for their support and assistance during the collection of the material on Madeira Island. Dr Grace A. Wyngaard (James Madison University, Harrisonburg, USA) kindly provided language editing. We are grateful to both reviewers for their helpful comments.

\section{References}

Alekseev V.R. 2008. Eucyclops albuferensis sp. nov. (Cyclopoida: Copepoda: Crustacea) from Albufera Lake, Valencia, Spain. Proceedings of the Zoological Institute RAS 312 (1/2): 127-134.

Alekseev V.R. 2010. Two new Eucyclops species (Cyclopiformes: Cyclopidae) from Spain. Zoosystematica Rossica 19 (2): 171-178. https://doi.org/10.31610/zsr/2010.19.2.171 
Alekseev V.R. 2019. Revision of the genus Eucyclops (Claus, 1893) and subfamily Eucyclopinae of the world fauna. Arthropoda Selecta 28 (4): 490-514. https://doi.org/10.15298/arthsel.28.4.03

Alekseev V.R. \& Defaye D. 2004. Eucyclops leschermoutouae sp. n. from Majorca, Balearic Islands (Crustacea, Copepoda, Cyclopidae). Zoosystematica Rossica 12 (2): 163-169.

Alekseev V.R. \& Defaye D. 2011. Taxonomic differentiation and world geographical distribution of the Eucyclops serrulatus group (Copepoda, Cyclopidae, Eucyclopinae). In: Defaye D., von Vaupel Klein J.C. \& Suárez-Morales E. (eds) Studies on Freshwater Copepoda: A Volume in Honour of Bernard Dussart. Crustaceana Monographs vol. 16: 41-72. Koninklijke Brill NV, Leiden. https://doi.org/10.1163/9789004188280_003

Alekseev V., Dumont H.J., Pensaert J., Baribwegure D. \& Vanfleteren J.R. 2006. A redescription of Eucyclops serrulatus (Fischer, 1851) (Crustacea: Copepoda: Cyclopoida) and some related taxa, with a phylogeny of the E. serrulatus-group. Zoologica Scripta 35: 123-147.

https://doi.org/10.1111/j.1463-6409.2006.00223.x

Alekseev V.R., Yusoff F.M. \& Fefilova E.B. 2016. Continental copepod biodiversity in North-Eastern Borneo, Malaysia. Arthropoda Selecta 25 (2): 183-197. https://doi.org/10.15298/arthsel.25.2.05

Boieiro M., Aguiar A.F., Rego C., Borges P.A.V. \& Serrano A.R.M. 2015. The biodiversity of terrestrial arthropods in Madeira and Selvagens archipelagos. Revista IDE@ - SEA 6B (30-06-2015): 1-20. Available from http://sea-entomologia.org/IDE@/revista_06B.pdf [accessed 23 Apr. 2021].

Boxshall G.A. \& Braide E.I. 1991. The freshwater cyclopoid copepods of Nigeria, with an illustrated key to all species. Bulletin of the British Museum (Natural History) Zoology 57: 185-212.

Chang C.Y. 2009. Illustrated Encyclopedia of Fauna and Flora of Korea, 42, Inland-water Copepoda. Ministry of Education, Science and Technology of Korea, Seoul.

Defaye D. 1988. Contribution à la connaissance des Crustacés Copépodes d'Ethiopie. Hydrobiologia 164: 103-147. https://doi.org/10.1007/BF00008454

Defaye D. \& Dussart B. 1991. Sur les Crustacés Copépodes des Açores. Annales de Limnologie 27 (2): 119-132. https://doi.org/10.1051/limn/1991009

Dev Roy M.K. \& Venkataraman K. 2018. Catalogue on copepod fauna of India. Part 2. Cyclopoida and Harpacticoida (Arthropoda: Crustacea). Journal of Environment and Sociobiology 15 (2): 109-194.

Dussart B. \& Defaye D. 2006. World Directory of Crustacea Copepoda of Inland Water II - Cyclopiformes. Backhuys Publishers, Leiden.

Fernández-Palacios J.M., de Nascimento L., Otto R., Delgado J.D., García-del-Rey E., Arévalo J.R. \& Whittaker R.J. 2011. A reconstruction of Palaeo-Macaronesia, with particular reference to the longterm biogeography of the Atlantic island laurel forests. Journal of Biogeography 38: 226-246. https://doi.org/10.1111/j.1365-2699.2010.02427.x

Fischer S. 1860. Beiträge zur Kenntnis der Entomostraceen. Abhandlungen der MathematischPhysikalischen Classe der Köeniglichen Bayerischen Akademie der Wissenschaften 8: 647-682 + Pls XX-XXII.

Freitas R., Romeiras M., Silva L., Cordeiro R., Madeira P., González J.A., Wirtz P., Falcón J.M., Brito A., Floeter S.R., Afonso P., Porteiro F., Viera-Rodríguez M.A., Neto A.I., Haroun R., Farminhão J.N.M., Rebelo A.C., Baptista L., Melo C.S., Martínez A., Núñez J., Berning B., Johnson M.E. \& Ávila S.P. 2019. Restructuring of the 'Macaronesia' biogeographic unit: A marine multitaxon biogeographical approach. Scientific Reports 9: 15792 https://doi.org/10.1038/s41598-019-51786-6 
Gaponova L. \& Hołyńska M. 2019. Redescription and relationships of Eucyclops persistens (Copepoda: Cyclopidae) endemic to the Azov-Black Sea basin. Annales Zoologici 69 (2): 427-446.

https://doi.org/10.3161/00034541ANZ2019.69.2.010

Ghaouaci S. 2018. Biodiversity and Distribution of the Crustacean Fauna of the Continental Waters of Northeastern Algeria. $\mathrm{PhD}$ thesis, Badji-Mokhtar Annaba University, Algeria.

Ghaouaci S., Amarouayache M., Gouasmia G. \& Hołyńska M. 2017. An annotated checklist of the freeliving cyclopoids (Copepoda: Crustacea) of Algeria. 13 ${ }^{\text {th }}$ International Conference on Copepoda, July 16-21, 2017 Cabrillo Marine Aquarium, Los Angeles, Abstract Book: 90.

Hamaidi F., Defaye D. \& Semroud R. 2010. Copepoda of Algerian freshwater: Checklist, new records, and comments on their biodiversity. Crustaceana 83 (1): 101-126.

https://doi.org/10.1163/001121609X12512848343603

Ishida T. 1998. Eucyclops biwensis, a new cyclopoid copepod (Crustacea) from lake Biwa, Japan, with records of a morphologically identical population of the new species and Eucyclops roseus from Lake Victoria, Kenya. The Bulletin of the Biogeographical Society of Japan 53 (2): 23-27.

Ishida T. 2002. Illustrated fauna of the freshwater cyclopoid copepods of Japan. The Bulletin of the Biogeographical Society of Japan 57: 37-106.

Karlsson M. \& Karlsson M. 2019. An account of Lamprologini, including Neolamprologus sp. "Mwila", a new shell-dwelling species from Mwila Island in the Kipili Archipelago, the facts about N. sp. "Eseki", the whereabouts of Kinyamkolo, and much more.

Available from https://blog.africandivingltd.com/2019/03/lamprologinipart-2.html [accessed 23 Apr. 2021].

Kiefer F. 1933. Die freilebenden Copepoden der Binnengewässer von Insulinde. Archiv für Hydrobiologie Suppl 12 "Tropische Binnengewässer IV”: 519-621.

Kiefer F. 1939. Scientific results of the Yale North India Expedition. Biological Report no. 19. Freilebende Ruderfusskrebse (Crustacea, Copepoda) aus Nordwest und Südindien (Pandschab, Kaschmir, Ladak, Nilgirigebirge). Memoirs of the Indian Museum 13 (2): 83-203.

Koźmiński Z. 1936. Morphometrische und ökologische Untersuchungen an Cyclopiden der strenuusGruppe. Internationale Revue der gesamten Hydrobiologie und Hydrographie 33: 161-240.

https://doi.org/10.1002/iroh.19360330302

Lindberg K. 1939. Une révision des représentants indiens du sous-genre Eucyclops s. str. (Groupe serrulatus). Records of the Indian Museum 41: 373-400.

Lindberg K. 1962. Cyclopides (Crustacés, Copépodes) des Açores. Boletim do Museu Municipal do Funchal 15: 5-19.

Mercado-Salas N.F., Suárez-Morales E. \& Silva-Briano M. 2016. Taxonomic revision of the Mexican Eucyclops (Copepoda: Cyclopoida) with comments on the biogeography of the genus. Journal of Natural History 50 (1-2): 25-147. https://doi.org/10.1080/00222933.2015.1061715

Monchenko V.I. 2003. [Free-living Cyclopoid Copepods of Ponto-Caspian Basin]. Naukova Dumka, Kiev. [In Russian.]

Raposeiro P.M., Cruz A.M., Hughes S.J. \& Costa A.C. 2012. Azorean freshwater invertebrates: Status, threats and biogeographic notes. Limnetica 31 (1): 13-22 + Annex I-III.

https://doi.org/10.23818/limn.31.02 
Rego C., Boieiro M., Vieira V. \& Borges P.A.V. 2015. The biodiversity of terrestrial arthropods in Azores. Revista IDE@ - SEA 5B (30-06-2015): 1-24. Available from http://sea-entomologia.org/IDE@/revista_05B.pdf [accessed 23 Apr. 2021].

Sars G.O. 1909. Zoological results of the Third Tanganyika Expedition, conducted by Dr. W. A. Cunnington, F.Z.S., 1904-1905.- - Report on the Copepoda. Proceedings of the Zoological Society of London: 31-77 + Pls VI-XXIII. https://doi.org/10.1111/j.1096-3642.1909.tb01855.x

Tai A.Y. \& Chen G.X. 1979. Cyclopoida. In: Shen C-J. \& Fauna Editorial Committee (eds) Fauna Sinica, Crustacea, Freshwater Copepoda: 301-420. Science Press, Peking. [In Chinese.]

Tang D. \& Knott B. 2009. Freshwater cyclopoids and harpacticoids (Crustacea: Copepoda) from the Gnangara Mound region of Western Australia. Zootaxa 2029: 1-70.

https://doi.org/10.11646/zootaxa.2029.1.1

Triantis K.A., Borges P.A.V., Hortal J. \& Whittaker R.J. 2010. The Macaronesian province: patterns of species richness and endemism of arthropods. In: Serrano A.R.M., Borges P.A.V., Boieiro M. \& Oromí P. (eds) Terrestrial Arthropods of Macaronesia - Biodiversity, Ecology and Evolution: 49-71. Security Print - Sociedade de Indústria Gráfica, Lda. Lisbon.

Vecchioni L., Sala J., Arculeo M. \& Marrone F. 2020. On the occurrence of Eudiaptomus gracilis (G.O. Sars, 1863) (Copepoda: Diaptomidae) in Madeira (Portugal). Limnetica 39 (2): 571-578.

https://doi.org/10.23818/limn.39.37

Manuscript received: 14 October 2020

Manuscript accepted: 3 March 2021

Published on: 13 May 2021

Topic editor: Koen Martens

Desk editor: Radka Rosenbaumová

Printed versions of all papers are also deposited in the libraries of the institutes that are members of the EJT consortium: Muséum national d'histoire naturelle, Paris, France; Meise Botanic Garden, Belgium; Royal Museum for Central Africa, Tervuren, Belgium; Royal Belgian Institute of Natural Sciences, Brussels, Belgium; Natural History Museum of Denmark, Copenhagen, Denmark; Naturalis Biodiversity Center, Leiden, the Netherlands; Museo Nacional de Ciencias Naturales-CSIC, Madrid, Spain; Real Jardín Botánico de Madrid CSIC, Spain; Zoological Research Museum Alexander Koenig, Bonn, Germany; National Museum, Prague, Czech Republic. 